\title{
U⿱宀⿻三丨口
}

\section{Overwash-dominated stratigraphy of barriers with intermittent inlets}

Green, A., Pillay, T., Cooper, A., \& Guisado-Pintado, E. (2019). Overwash-dominated stratigraphy of barriers with intermittent inlets. Earth Surface Processes and Landforms, 44(11), 2097-2111.

https://doi.org/10.1002/esp.4631

Link to publication record in Ulster University Research Portal

\section{Published in:}

Earth Surface Processes and Landforms

Publication Status:

Published (in print/issue): 15/09/2019

DOI:

10.1002/esp.4631

\section{Document Version}

Author Accepted version

\section{General rights}

Copyright for the publications made accessible via Ulster University's Research Portal is retained by the author(s) and / or other copyright owners and it is a condition of accessing these publications that users recognise and abide by the legal requirements associated with these rights.

\section{Take down policy}

The Research Portal is Ulster University's institutional repository that provides access to Ulster's research outputs. Every effort has been made to ensure that content in the Research Portal does not infringe any person's rights, or applicable UK laws. If you discover content in the Research Portal that you believe breaches copyright or violates any law, please contact pure-support@ulster.ac.uk. 
Green Andrew (Orcid ID: 0000-0001-9438-1315)

Guisado-Pintado Emilia (Orcid ID: 0000-0003-1115-4059)

\section{Overwash-dominated stratigraphy of barriers with intermittent inlets}

\section{Green, A.N. ${ }^{1}$, Pillay, T. ${ }^{1}$, Cooper, J.A.G. ${ }^{1,2}$, Guisado-Pintado, E. ${ }^{3}$}

${ }^{1}$ Geological Sciences, School of Agricultural, Earth and Environmental Sciences, University of KwaZulu-Natal, South Africa

${ }^{2}$ School of Geography and Environmental Science, University of Ulster, Coleraine, Northern Ireland, UK

${ }^{3}$ Department of Physical Geography and Regional Geographic Analysis, University of Seville, Seville 41004, Spain

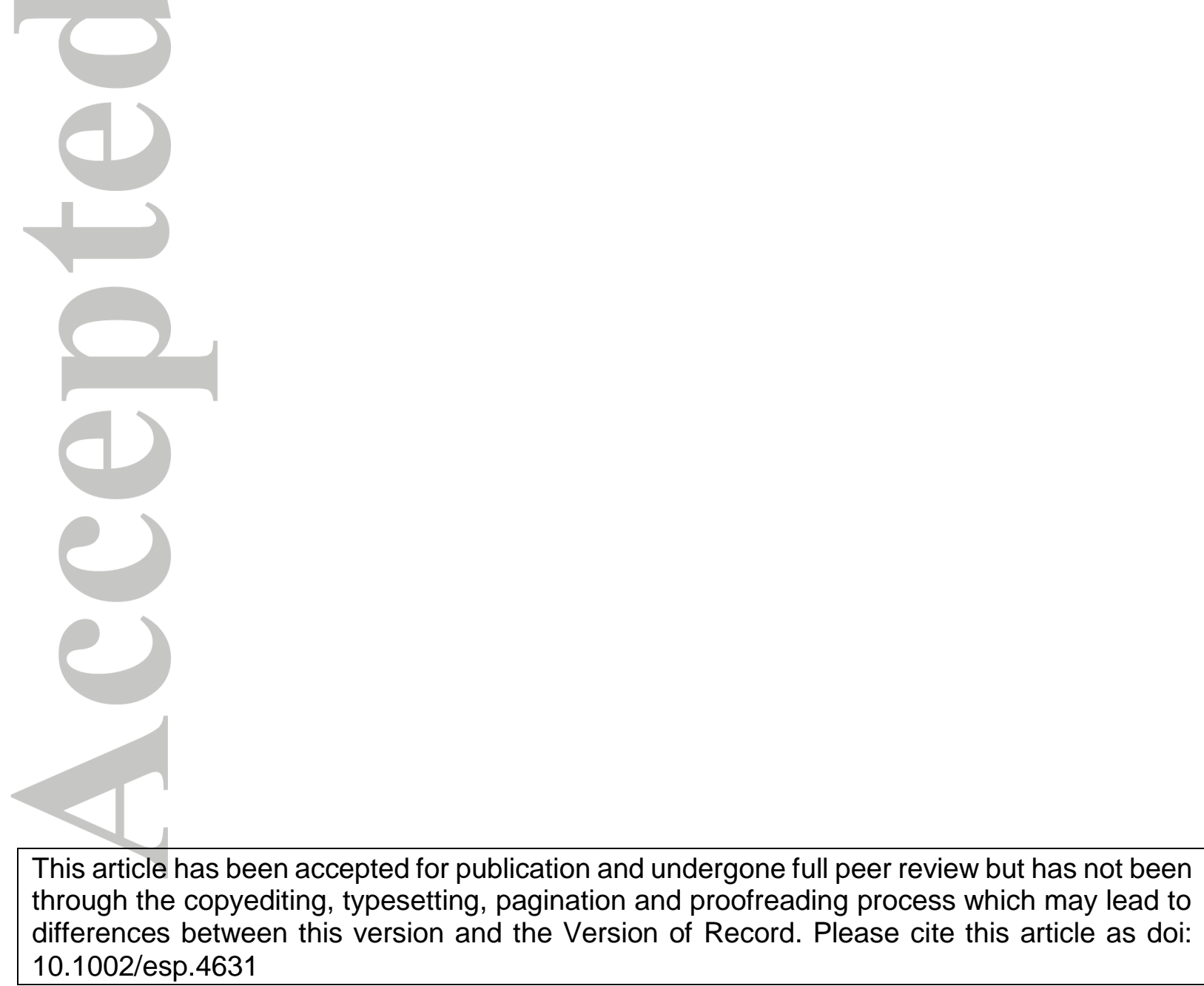




\section{Abstract}

The morphodynamics and structure of barriers with persistent tidal inlets have been well studied. In contrast the stratigraphy and functioning of barrier systems with ephemeral inlets is poorly understood. This paper examines the barrier-inlet systems of two intermittently closed open lagoons or temporarily open closed estuaries on the east coast of South Africa. Multiple geophysical surveys using ground-penetrating radar (GPR) were correlated with exposed sections of the barrier where inlet formation revealed the internal stratigraphy. Stratigraphic observations were placed in the context of the contemporary wave dynamics and mesoscale geomorphic evolution. The integrated databases reveal an absence of migrating channel features. Instead the stratigraphy is dominated by landward dipping sheets of alternating highand low-amplitude reflectors. These correlate with gravel, shell debris and heavy mineral-lined beds formed by overwash processes. Where ephemeral inlet structures are preserved in the stratigraphy, their fills comprise aggrading, high-amplitude reflectors, linked to washover infilling of the inlet mouth. Multiple small channels in the more distal portions of the barrier in georadar stratigraphy are related to channelized washover flow.

These barriers often breach during high swell and are subsequently sealed during fairweather wave conditions. Time series analysis of waves and satellite imagery shows a link between storms from the south and breach events. This is consistent with the truncations in subsurface images and inferred barrier lowering by overwash channelling. These barriers experience quasi-stable oscillations in their landward and seaward shore position, punctuated by periods of barrier roll over associated with the most intense storms. As overwash is responsible in part for both the constructive and destructive phases of the barrier, these barriers have low preservation potential. Persistent rollover driven by overwashing will terminate once accommodation space is eliminated and the barriers are eroded by storm activity. 


\section{Introduction}

Barrier stratigraphy provides an insight into the processes of barrier development and dynamics in the geological record. Many studies of barrier structure and stratigraphy (including their associated inlets) have enabled the development of generic stratigraphic models (Oertel, 1985; Reinson, 1992). In many such models, the barriers on coastal plains are dominated by distinctive sedimentary signatures associated with migrating tidal inlets driven by longshore sediment transport (FitzGerald et al., 2001; Mallinson et al., 2010; Hein et al., 2014; Maio et al., 2014; FitzGerald et al., 2015). These are coupled with complex back-barrier stratigraphic signatures including salt marsh and lagoonal deposits that reflect, amongst other controls, a strong inheritance of the local bedrock framework on both inlet and barrier evolution (Cooper et al., 2018). The morphological changes and resulting barrier stratigraphy are related to episodic events such as channel deflections, breaching, and sediment bypassing (Tye and Moslow, 1993; FitzGerald et al., 2012). In this respect, the barrier island lithosome is very likely to comprise inlet and marginal flood channel deposits (Moslow and Heron, 1978; FitzGerald et al., 2012), which can be used to reconstruct, through the analysis of subsurface images using ground-penetrating radar (GPR), the complex evolution of a barrier shoreline (Costas and FitzGerald, 2011) and its relationship with past high-energy episodes.

The stratigraphy of small barriers associated with ephemeral inlets have received little attention. Aubrey and Giese (1993, and references therein) discuss the origins and evolutionary trends of a variety of inlets, however, these occur on scales larger spatial and temporal scales to those of smaller inlets systems. These include the barriers associated with Intermittently Closed Open Lagoons (ICOLS) or Temporarily Open Closed Estuaries (TOCE'S) (Ranasinghe et al., 1999) that are common on many bedrock-influenced coasts worldwide, including the western United States, South Africa and SE Australia (Elwany et al., 1998; Cooper, 2001a; 
Haines et al., 2006). However, few studies of the barrier architecture of these transgressive systems and associated ephemeral inlets have been undertaken.

Geophysical investigations coupled with temporal geomorphological observations have much potential to elucidate the mesoscale morphological behavior of these systems. For instance, Costas et al. (2006) demonstrated that the combined use of geophysical data with aerial imagery for deriving shoreline positions is a powerful tool to establish the geochronological control for erosional surfaces identified in the GPR images. Buynevich and Donelly (2006), showed that using a GPR over the sites of former inlets revealed complex patterns of channel migration and infilling driven by barrier breaching and formation of ephemeral channels. In this paper we describe the internal structure of two small barriers in SE South Africa using GPR imaging and field mapping, and interpret it in the context of contemporary mesoscale behaviour. In relating the formative processes to the longer-term stratigraphic signatures, we aim to assess the relative preservation potential of these types of barriers in the sedimentary record.

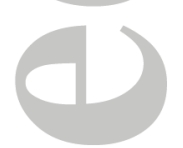

\section{Ephemeral inlets and associated barriers and estuaries}

Ephemeral inlet systems form in the context of wave-dominated, microtidal environments. The associated estuaries fit into Davies (1964) and Roy's (1984) microtidal classification scheme (Cooper, 2001a), and are widely regarded as zones of net sediment accumulation (Roy, 1984), with both allochthonous (e.g. wave, aeolian and fluvial) and autochthonous (e.g. in situ organic materials) inputs (Cooper, 1995). The estuaries consist of narrow sandy barriers, narrow inlets, and relatively small back-barrier systems (Cooper, 2001b). Many are hosted within bedrockincised valleys which provide a spatial constraint on the evolution of the estuary (cf. Roy et al., 2001) and in many cases help to control the positioning and behaviour of both the inlets and barriers (e.g., Cooper, 1994). 
These systems appear to preferentially develop in areas of steep hinterland gradient, which inhibits tidal incursion (Cooper, 2001a). The extension of the river channel to the inlet can also reduce the tidal prism such that the inlet itself is maintained by river discharge rather than tidal currents (Cooper, 1994). During periods of low fluvial discharge, the inlets close entirely and water inputs are balanced by evaporation and seepage through the barrier. Inlets re-open during periods of increased discharge (Clarke et al., 2014; 2017). Extreme fluvial floods act to scour the estuary channel, and remove fluvial and barrier sediment (Cooper et al., 1990; Cooper, 2002). The opening mechanisms for inlets can be diverse, and include overwashing and breaching during storms (e.g., Froneman, 2004; Bond et al., 2013); fluvial flooding (e.g., Green et al., 2013; Clarke et al., 2017); and the combination of the two.

If barriers exhibit coast-parallel extension, floods may create new tidal inlets that may (Green et al., 2013) or may not migrate within the confined of adjacent bedrock headlands (Cooper, 1993). The inlets have small tidal prisms that are not able to overcome wave-induced sediment transport (Cooper, 1990; Cooper 2001a). Lowered stream flow, accompanied by large ocean waves results in what Baldock et al. (2008) document as "ephemeral entrances that respond to process forcing almost instantaneously on a geomorphic timescale, with closure by a supratidal berm of depositional origin". The limited accommodation space in these types of systems (cf., Morris and Turner, 2010) further predisposes the inlet to rapid infilling. All these factors limit the potential for longshore (lateral) inlet migration.

\section{Regional setting}

The study area is located on the KwaZulu-Natal coast of South Africa (Fig. 1). The coastline experiences a swell-dominated wave regime, with a spring tidal range of $1.84 \mathrm{~m}$, and a neap range of $0.5 \mathrm{~m}$. Mean significant wave height (Hs) is $1.59 \mathrm{~m}$ (Smith et al., 2010), though storm- 
driven swells during March 2007 had a significant wave height of $8.5 \mathrm{~m}$ (Table 1) (Smith et al., 2010) and were associated with significant coastal erosion. Dominant waves approach from the SE, with a subordinate ENE component. The coast is orientated at $042^{\circ}-222^{\circ}$, with a northerly longshore transport that is enhanced during the more energetic winter swell regime (Smith et al., 2010).

The rivers of the KwaZulu-Natal coastline drain a steep hinterland with an average gradient greater than 1:100 (Cooper, 1990). Fluvial sediment supply is consequently high. The estuaries occupy bedrock-incised valleys that limit the lateral accommodation of the systems and form solid boundaries within which estuary barriers form and migrate (Cooper, 2001). The estuaries that are enclosed by these geologically constrained barriers (Loureiro et al., 2012) are typically shallow (less than $2 \mathrm{~m}$ deep when the barriers are intact) and they drain almost entirely when the barrier breaches (Cooper, 2001).

Two coastal barriers were examined at Zinkwazi and Umdloti (Fig. 1). The Zinkwazi River has a small river catchment (approximately $75 \mathrm{~km}^{2}$ ) and is incised into deeply weathered Pleistocene soils (McCormick et al., 1992). The river has a mean annual runoff of $14.3 \times 10^{6}$ $\mathrm{m}^{3}$ (Chew and Bowen, 1971), with an estimated sediment yield of 29200 tonnes per year (Rooseboom, 1975). The inlet forms in the wave shadow of a rocky headland (in the southern part of the barrier), with the estuary located in a headland-bound embayment. The $\sim 250-\mathrm{m}-$ long sandy barrier has a swash-aligned morphology and the volume of fluvial discharge controls the length of time the estuary remains open to the Indian Ocean (Bond et al., 2013).

The Umdloti River catchment covers an area of $558 \mathrm{~km}^{2}$, with a mean annual run off of $112 \mathrm{x}$ $10^{6} \mathrm{~m}^{3}$ (Heydorn and Pistorius, 1978). The estuary is marked by a $600-\mathrm{m}$-long barrier that typically breaches in the south, although ephemeral inlets have been recorded along most of its length (Garden and Garland, 2005). Like the Zinkwazi estuary, the barrier is drift-aligned, and 
is occasionally underlain by aeolianite which forms the southernmost bedrock pinning point of the system (Cooper and Green, 2016).

\section{Methods}

Detailed GPR surveys were undertaken at both the Umdloti and Zinkwazi barriers, with profiles oriented either parallel to the main barrier crest or perpendicular to the trend of the barrier. A total of $\sim 3.5 \mathrm{~km}$ of line coverage from the two areas was achieved (Fig. 1). The internal stratigraphy was examined using a PulseEKKO PRO ${ }^{\text {TM }}$ Sensors and Software GPR system. Two separate operating frequencies (100 and $200 \mathrm{MHz}$ ) were employed. The $100 \mathrm{MHz}$ and $200 \mathrm{MHz}$ antennae were used for replicate lines to provide adequate depth of penetration as well as, high-resolution 2D images of the subsurface geology. The $100 \mathrm{MHz}$ radargrams reached a penetration of $12 \mathrm{~m}$, whereas the $200 \mathrm{MHz}$ radargrams penetrated to $9 \mathrm{~m}$. A Trimble ProXRT GPS receiver was coupled to the GPR. This system allows for a $1 \mathrm{~Hz}$ re-positioning rate with uncorrected sub-meter accuracy and with a higher positional accuracy obtainable with post-processing.

Once the data were collected along each GPR profile, the data differentially corrected using a multiple base station approach from the RTK feeds supplied from the Ulundi and Richards Bay beacons (Fig. 1). The positioning data have a horizontal and vertical accuracy of $10 \mathrm{~cm}$. These data were used to topographically correct the GPR transects. EKKO Project software (v.5) was used to process and display the geophysical data. All lines were then processed in the LineView program by filtering and optimising of gains. For both the 100 and $200 \mathrm{MHz}$ radargrams, the Dewow and SEC2 filters were used. The average subsurface radar-wave velocity for dry sand was considered $0.15 \mathrm{~m} / \mathrm{ns}$ based on the empirical value calculated (Sensors and Software, 1993). All time-depth conversions were extrapolated from this. 
The various radar facies identified from the GPR profiles were correlated with lithostratigraphic units of the barrier that were exposed by breaching. Such exposures were used to optimise the ground truth of the geophysical coverage. Measured sections were examined according to standard sedimentological procedures and sampled for grain size, organic debris and macrofossil content. Samples were collected every $10 \mathrm{~cm}$, or where a notable change in facies was noted. These were analysed using a mechanical sieve shaker with a sieve set stacked at 1-phi intervals to separate individual sand fractions within a range from gravel through to fine sand. Mean diameters and sorting values were determined on the basis of percentile statistics after Folk and Ward (1957). Sediment classification follows the modified Wentworth scheme (Tanner, 1969).

Satellite images (Google Earth) of the Zinkwazi and Umdloti Barriers were analysed to assess recent geomorphic changes to each system. These span a fourteen-year period from 2002 to 2016 for the Umdloti system, and a six-year period (2010 to 2016) for the Zinkwazi system. All images were geo-referenced and imported into ArcGIS where both mesoscale changes in barrier morphology, and seasonal variability in inlet behaviour were examined.

To complement the assessment of mesoscale changes in the system, a time series analysis of the general wave climate was undertaken for the period represented in the air photos and GPR surveys. Given the absence of a single and suitable dataset spanning the study period (20022016), two different wave time series were used to characterize the hydrodynamic conditions. The directional Datawell Waverider Mk 4 buoy $\left(28.8^{\circ} \mathrm{S}, 32^{\prime \prime} \mathrm{E}\right.$ in $22 \mathrm{~m}$ water) situated in Richards Bay, 22km to the north, and the WW3 NCEP (29.5 S, 31.5 E) model from NOAA were both used. The Richards Bay buoy produced wave data for every 3 hours from 1979 to 2007. Point 6023, located $25 \mathrm{~km}$ SE offshore Zinkwazi, was used to extract 3 hours of wave records from the WW3 NCEP model (based on WaveWatch III) for the period comprising 2006 to 2016. The data were statistically compared with the Directional Datawell Waverider Mk 4 
buoy with a good correlation between both datasets found $\left(\mathrm{R}^{2}=0.79\right)$, thus indicating that the suitability of the WW3 NCEP data for the representation of wave climate conditions for the study area.

A storm wave event is defined as a wave event during which the maximum Hs exceeds $5 \%$ of the record (Almeida et al. 2011; Masselink et al. 2015; Guisado-Pintado and Jackson, 2018). In this case the threshold was Hs $\geq 2.99 \mathrm{~m}$ for the WW3 NCEP model wave data. The start and end of the storm event were defined when Hs exceeds or falls below the $10 \%$ exceedance wave height (Hs is $\geq 2.58$ ). In all cases, storm durations that exceeded $>12 \mathrm{~h}$ were considered to incorporate high-tide conditions where run-up would be greatest.

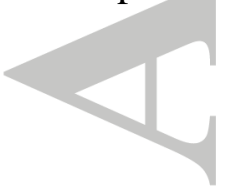

\section{Results}

GPR stratigraphy and sedimentary architecture

\section{Umdloti}

GPR transects reveal the Umdloti barrier to comprise a repetitive series of low-angle $\left(1-3^{\circ}\right)$, landward-dipping, medium-amplitude reflectors. These form sheets that are frequently truncated by overlying, steeper dipping reflectors (Fig. 2 a-b). Landwards of the barrier crest, landward-dipping discontinuous planar and higher amplitude chaotic reflectors form lenticular, landward-pinching wedges of sediment with occasional concave-up reflectors (Fig. 2). The lenticular packages and planar landward-dipping sheets are separated by horizontal reflectors, especially close to the barrier crest. The beds are laterally continuous along strike, with occasional overlapping hyperbolics, interspersed with isolated and small ( 0.5 m deep) incisions that truncate the underlying stratigraphy (Fig. 3). A single, deep incision imaged in the northernmost barrier truncates the stratigraphy to mean sea level (MSL) (Fig. 3). The incision is filled with planar, high-amplitude reflectors with occasional small, channel-like 
depressions ( $\sim 1 \mathrm{~m}$ wide, $20 \mathrm{~cm}$ deep). This is truncated by a package of the landward-dipping reflectors, the base of which is marked by an undulating reflector of amalgamated broad and low-relief concave-up reflections. This surface is strongly associated with multiple overlapping hyperbolic reflectors (Fig. 3).

The sedimentary architecture of the Umdloti barrier exposed in modern scarps is marked by gently landward-dipping layers of medium to coarse sand (Fig. 2c), and, like in the GPR stratigraphy (Fig. 2), minor truncations between the various packages are evident. The sheets terminate landward in a series of lobate washover fans, and seaward of the barrier crest are truncated by steeply seaward-dipping, planar-bedded medium sands of the beachface (Fig. 2c).

The basal erosional horizon is marked by heavy-mineral laminations, which line the scarp. The corresponding GPR data are unclear due to saltwater attenuation seaward of the berm. When exposed, the steeper, seaward dipping strata are clearly onlapped to seaward by horizontal layers of medium sand (Fig. 2).

\section{Zinkwazi}

The Zinkwazi barrier is similarly composed mainly of sheets of medium-amplitude, landward dipping planar reflectors, interspersed by occasional lobate sediment bodies with chaotic to discontinuous inclined reflectors and occasional concave up reflectors (Fig. 4). These are erosionally truncated by a planar surface with numerous shallow depressions. A single prominent depression, $20 \mathrm{~m}$ wide and $1 \mathrm{~m}$ deep, is associated with a very strong overlapping hyperbolic reflector pattern in the middle of barrier (Fig. 4). A series of steeply seawarddipping truncating reflectors underlie much of the barrier to the north (Fig. 4). These truncate the landward-dipping sheets and are onlapped in turn by seaward prograding, high-amplitude reflectors that form seaward-pinching wedges. This succession is capped by the landward- 
dipping, planar reflector facies pattern. The southernmost extent of the barrier is underlain by a series of high-amplitude, planar reflectors that dip steeply to the northeast (Fig. 5). These can be traced from subcrop into the adjoining rocky outcrop that forms the southern headland. The upper surface of this bedrock package is onlapped and downlapped by northward-prograding, medium-amplitude reflectors. Apart from the steep sided topography of the bedrock, there are no discernible channel features such as in the Umdloti example (Fig. 3).

The sedimentary architecture of the barrier is dominated by sheets of medium sand, interspersed with 10-cm-thick beds of coarse sand comprising rounded quartz and shell hash, each of which corresponds to respective planar, landward dipping low and higher-amplitude reflectors (Fig. 6). These overlie a basal, heavy-mineral and shell debris-lined erosional scarp (Fig. 6), which correlates with the truncations evident in the GPR data (Fig. 5). Landward of the steeply seaward-dipping truncation, the material comprises fine sand. The upper barrier stratigraphy is dominated by medium sands with erosional bases lined with heavy minerals, fining up into units of fine quartz sand (Fig. 6). The capping units are mainly fine aeolian sand, however the seaward units are capped by recent, minor overwash strata evidenced by increased abundance of shelly debris. Small pebbles and abundant granules mark the most recent washovers along the top of the barrier and identical deposits are preserved in the stratigraphy as 1-m-long landward pinching lenses (Fig. 6).

Inlet and barrier morphodynamics

The morphodynamic functioning of the two barriers is relatively similar (Fig. 7 and 8). Each follows regular episodes of opening and closing of ephemeral inlets interspersed with regular overwashing. Both systems repeatedly form inlets in a single place, each inlet being $<10 \mathrm{~m}$ wide and cutting downward to about mean low water. The Umdloti barrier inlet occurs in the 
north and the Zinkwazi inlet to the south of the barriers, both in areas where the barrier is narrowest. An inlet does occasionally form in the central portions of the Umdloti barrier, marked by a low point in the barrier elevation and an elongate spit attached in the backbarrier (Fig. 7c, f). Historical satellite imagery shows that the inlets do not migrate along the barrier; rather they open and are then rapidly $(<1$ month) closed by successive washover events.

In both systems, washover fans occur in close association with the inlets. Multiple lobate fans accumulate in the backbarrier throughout the year (e.g. Fig. 7 b, d, k-m), and fill in any topographic irregularities in the barriers (Fig. 7c-d; i-j). Protracted overwashing occurred in the Umdloti system during stormy conditions in 2002, 2009, 2011, and 2012 (Fig. 7a, d) (Fig. 71, and $\mathrm{m}$ ), and was marked by an average landward shift of the landward edge of the barrier up to $35 \mathrm{~m}$. In 2007, washover deposits (Fig. 7b) along the barrier were associated with inlet closure and major sediment influx into the lagoon during the March 2007 swell event (Table 1), with the backbarrier shoreline shifting approximately $45 \mathrm{~m}$ landward (Fig. 7b). This marks a new quasi-stable equilibrium position around which only minor shifts $( \pm 15 \mathrm{~m})$ in the barrier shoreline have since occurred.

In the Zinkwazi system, prominent washover fans are evident on the 2010, 2011, 2012, and 2014 images (Fig. 8a, b, e, j-1). Missing from the satellite imagery is the March 2007 swell event, however, Bond et al. (2014), reported a $100 \mathrm{~m}$ landward shift in the barrier and complete filling, by washover materials, of the inlets in response to that storm. Over the 2010 and 2011 period, cumulative washover extended the backbarrier shoreline a further $25 \mathrm{~m}$ landwards (Fig. $8 \mathrm{a}, \mathrm{b}, \mathrm{e}, \mathrm{j}-\mathrm{l})$. In both systems, the washover fans appear to be persistent geomorphic features, only overprinted by successive overwash events.

Digital terrain models for the Zinkwazi barrier extracted from data presented by Bond et al. (2014) are presented in figure 9. These represent a pre- and post-2007 morphological state of 
the barrier. Prior to the major period of overwash that drove the barrier landward, a prominent scarp $\sim 2 \mathrm{~m}$ high was formed in the northern part of the barrier. South of the scarp, the barrier maintained a relatively uniform width. After the 2007 event, the scarp was blanketed by sediment and the beachface of the barrier prograded by up to $30 \mathrm{~m}$, though the southern areas, near the rocky headland retreated by up to $60 \mathrm{~m}$. Figure 5 is a GPR profile that crosses the scarped area. It is evident that the scarp is preserved in the GPR stratigraphy as a truncating surface, and that a series of aggrading chaotic and discontinuous reflectors onlap this feature to landward.

Hydrodynamic characterisation of storms

To characterize the wave forcing during the study period both, modal and storm conditions were defined. A mean Hs of $1.59 \mathrm{~m}$ was derived from the Richards Bay wave series and slightly bigger Hs for the WW3 NCEP model $(\mathrm{Hs}=1.81 \mathrm{~m})$ given its offshore position. The March Storm 2007 was the most energetic event of the past 28-year record with Hs=8.5 m (Moes and Roussouw, 2008) and T=16.6 s (Salzmann and Green, 2012) as measured from the National Ports Authority wave rider buoy offshore Richards Bay. The storm lasted over 72 hours. Only thirteen high-energy events have registered waves over $5 \mathrm{~m}$ in the area since 1979. These correspond with significant storm events in 1987, 1990, 1991, 1994, two events in 2002, two in 2007, 2011, two events in 2015 and two events in 2016. Seven of those events occurred during the study period (2002-April 2016).

Data analysis show that the breaching of barriers is often associated with onshore directed storms (E to SE) with a peak significant wave height $(\mathrm{Hs}) \geq 3.5 \mathrm{~m}$ (Fig. 10). For instance, during a large swell-event in November 2009 (Fig. 10) the Umdloti inlet breached the barrier and, similarly, an opening of the Zinkwazi inlet occurred in association with a storm in August 
2011 (Fig. 10 and Fig. 8c). The fairweather behaviour after each large swell event is characterized by the infill and sealing of the inlet, which normally does not take more than a month to occur. For example, the Zinkwazi inlet sealed a month after the opening in April 2015 when Hs $<2.5 \mathrm{~m}$. This process is normally accompanied by the presence of smaller swelldriven washover fans that develop during the weeks after the inlet formed (see figure 10). During the "recovery period", modal to moderate wave conditions $(\mathrm{Hs}<2.5 \mathrm{~m})$ dominate.

\section{Discussion}

Linking stratigraphy, sedimentology and morphodynamics

The GPR stratigraphy can be interpreted in association with the sedimentary architecture and observed morphodynamic functioning of the barrier-inlet. The dominance of the planar, landward-dipping reflectors in the barrier stratigraphy are interpreted (or correspond to) landward-dipping medium sands and shell debris that merge up-dip with contemporary washovers in the back-barrier. The implications are that sediment progrades inland via overwash, and is the primary driver in the aggradation of the barrier (e.g. Buynevich et al., 2004). According to Bennett et al. (2009) and Pascucci et al. (2009), these reflector geometries are typically associated with barrier-wide inundation by overwash or overtopping. This, however, is at odds with the observed morphodynamics in the study sites, where washovers are clearly restricted to localised depocenters with discrete fans (e.g., Fig. 7e; 8e). Other authors (Daly et al., 2002; Seminack and Buynevich, 2013) consider similar radar facies to indicate a change from washover aggradation to aeolian spit development. Based on the grain sizes of the intervening lower amplitude reflectors in the barrier studied here, it appears that these reflectors mark a transitional finer aeolian facies that represents aeolian-dominated intervals between 
overwash periods. This is confirmed by the capping horizontal reflectors at the berm crest which are currently being modified by aeolian processes (Fig. 6).

The thin lobate, chaotic facies within the overall landward dipping packages are associated with coarser lenses of granule to pebble material observed in cross section. The associated discontinuous and concave up reflectors may represent the internal stratification typically found within small overlapping washover channels (Shan et al., 2015). Elsewhere, undulatory erosional surfaces form small-channelled features that underlie these radar facies (Fig. 3 and 5) and are associated with overlapping hyperbolics. In cross section, these surfaces have occasional pebble material and heavy minerals, which we consider as erosional lags formed during washover events. The small channels are of comparable scale to channels cut by washover events elsewhere (e.g. Hine, 1979; FitzGerald et al., 2001) and suggest that reflectors, like those which overlie these surfaces, comprise an aggradational channel fill facies (Seminack and Buynevich, 2013) that conforms to horizontal channel fill when sediment is being transported into the channel from a seaward source. The lobes thus appear to mark the channelisation of overwash into the backbarrier and represent the more energetic and proximal expression of the overwash processes.

The radar and sedimentological structure of the larger channel infills are somewhat different. Examples of radar facies of barrier-inlet systems are well-described from the Eastern United States (e.g. Van Heteren et al., 1998; FitzGerald et al., 2001; Mallinson et al., 2010; Hein et al., 2012). These typically represent a series of high-angle lateral accretion surfaces that mark the migration of the inlet, often associated with spit progradation, in the direction of longshore sediment transport. The barrier-spit-inlet sequences of the Gulf of Maine, for example, (Van Heteren et al., 1998), show the formation of recurved spits which prograde inland, alternated with onshore migration of bars, which eventually weld to the beach system of the spit. Those systems are much larger and have a much more complex evolution and structure than those 
reported here. In both the Zinkwazi and Umdloti barriers, inlet sequences are poorly developed (e.g. Zinkwazi), or are preserved as planar horizontal to landward-dipping, aggrading mixed amplitude reflectors. Figures 2, 4 and 6 show the internal stratification of both barriers, through the inlet, and its relationship to the GPR profiles. The facies shown in the GPR profiles are linked to the sheets of coarse sandy material with shell debris and thus represent successive sheets of overwash-derived sand accumulating in the inlet throat. The overlying overlapping and concave-up chaotic facies (Fig. 3), as discussed above, represents small washover channelling in the proximal parts of the fans. In terms of contemporary morphodynamics, these inlets are stable in position and ephemeral in duration (Fig. 7 and 8). Their infilling is not driven by long-term migration, but rather by event-based inundation. Our data show that the inlet fill is dominated by the rapid choking of the inlet by washover. This causes the inlet floor to aggrade (as recorded in the GPR images) and eventually seals the mouth.

According to Cooper (1990), ephemeral stream-mouth bars are commonly generated by flooding events and act as temporary sinks of sediment offshore of the newly opened inlet. Most of this bar sediment is re-incorporated back into the barrier via the landward migration of the deposit through wave attack (Cooper, 1990), which quickly fills the inlet with washover deposits. This is a possible reason as to why the typical channel fill facies as observed by others from coastal barrier systems, are not evident in our GPR records. In contrast, overwash sheets of relatively uniform material are the most dominant stratigraphic signature. Our results also show that overwash during high wave events can also create ephemeral inlets. The truncations and apparent channelized flow evident on GPR sections support the inferred barrier lowering that must be associated with such events but which has not been directly observed.

Smaller inlets, such as those of the Zinkwazi and Umdloti barrier systems may close due to smaller, less intense storms that occur throughout the year (Fig. 10). This may be the result of the small tidal prisms and associated weak tidal currents that are readily overwhelmed by wave 
action (Cooper, 2001a; Bond et al., 2013). Current outflow is also diminished when the impounded lagoon water has drained, and tidal flows are dominant. At the mesoscale, washover and inlet closure events are common and are related to average, or above-average swell conditions (Fig. 10). This is also because river-dominated estuaries (such as the examples presented here) have limited inlet accommodation due to their steep inlet throats and reflective beach profile (Cooper, 2001). Inlets can be plugged with sediment quickly, especially with high-rates of longshore sediment supply or, if inlet modification or adjustment via migration does not occur.

We consider the buried, steeply seaward-dipping truncations observed in GPR records to mark the recent landward limit of storm-associated beachface retreat in each system (see figure 4 and 6). The truncations identified are identical to palaeo-scarps described by Dougherty et al. (2004) and Buynevich et al. (2007). The steeply inclined, tangential erosional surfaces are revealed in exposures to be lined by heavy minerals. Buynevich et al. (2004) consider palaeoscarps found in the barriers of southern Maine as evidence of past hurricane events and advocate the use of palaeo-scarps as a tool for reconstructing storm events on progradational coastlines where preservation potential is high. The barriers in the study area occur along a stable (Smith et al., 2016) or periodically eroding coastline (Cooper, 1991) and the preservation potential of these features is consequently low: successive scarping events erode former records and essentially reset the barrier farther landward, such that buried scarps mark the most landward beachface position reached during recent storms. The palaeo-scarps are overlain by a prograding package which we attribute to post-storm beach recovery.

The controlling factors of both transgressive and regressive barrier sequences include wave and tidal regime, source and amount of sediment available for transport, surface topography during progradation and retrogradation, as well as isostatic and eustatic changes in sea level (Kraft and John, 1979). As sea level rises, tidal inlet and washover deposition play an important role 
in the development of narrow barriers (Buynevich and FitzGerald, 2003). This process is clear from both the stratigraphy and mesoscale dynamic analysis of the barriers of this study. In both examples, the barrier form is wholly dominated by washover events, and comprises a monotonously retrogradational arrangement of packages. These are very different from barrier stratigraphy elsewhere, which contain multiple packages related to beachface and shoreface progradation and inlet migration.

The profile response of barriers to sea-level rise is often viewed in terms of three competing models (Cooper et al., 2018). These include erosion, where the barrier sediment is redistributed into the shoreface (e.g., Belknap and Kraft, 1985), rollover, where the barrier translates landward with rising sea level (Carter, 1986), or overstepping, where the barrier is drowned in situ on the newly formed shoreface (e.g., Storms et. al., 2003). These factors are usually defined by the ambient energy of the system. High-wave and tidal energy predisposes barriers to erosion, whereas rapid rates of sea-level rise in less energetic environments may promote rollover (Tillmann and Wunderlich, 2013). We consider that despite the general high wave energy of the systems described (modal Hs $=1.81 \mathrm{~m})$, the net landward-directed and washoverbased geometry points to an overall landward migration of these barriers in line with the "rolling over" model. The mesoscale adjustment of the barriers likewise shows the progressive landward movement of the backbarrier shoreline (see Fig. 8). This long-term rollover, however, is punctuated by periods of storm-driven recession and intervening accretion. Major storms, however, have potential to move the barrier off its 'normal' footprint, establishing a new equilibrium position. The March 2007 swell event set the backbarrier shoreline back by $40 \mathrm{~m}$ and $\sim 100 \mathrm{~m}$ in the Umdloti and Zinkwazi systems, respectively (Bond et al., 2014), moving both barriers to a position landward of their former footprint. In the subsequent 11 years, the backbarrier shoreline has re-established a new geomorphic hinge point around which smaller quasi-stable oscillations are occurring, set back at least $40 \mathrm{~m}$ from the previous point. 
The predisposition of these barrier-spits to rollover is important to their net preservation potential in the long term. Buynevich (2007) showed that the geomorphic evolution of similarly coast-normal, elongate, barrier-fronted coastal waterbodies may be controlled more by shorterterm processes such as overwash, when compared to longer term rises in sea level coupled to barrier rollover. The South African barriers reported here are almost wholly constructed and driven by overwash. Consequently, the fate of the back barrier accommodation is intrinsically linked to shallowing of the system by washover deposits. Given smaller rises in sea level, this will be a major factor in the back-barrier evolution of these systems.

Green et al. (2014) showed a series of preserved barriers located on the adjoining shelf of the study areas, though these are of much larger scale when compared to the systems that front the river-dominated estuaries of South Africa. The barriers found on the shelf were rapidly cemented. Both their large volume and early cementation resulted in these features being overstepped during rising sea levels and thus ultimately preserved in the stratigraphic record (Green et al., 2018). When coupled with coastal retreat, and in hand with the continuing backbarrier aggradation due to washover accumulations, the smaller barrier-spits would rollover until no available accommodation space exists. The steep coastal hinterland and bedrockframed setting will further limit potential back-barrier flooding for a given increment of sea level rise (Buynevich, 2007). The pinning of the retreating barrier against this steeper topography will eventually result in complete reworking by the very storm-wave processes that act to form the barriers. Their net preservation potential as persistent features in the stratigraphy is thus low. Isolated examples of smaller in situ drowned barrier spits have been imaged in a series of incised valleys offshore the SE African coast (Green et al., 2013b), though these are uncommon and probably relate to a lower antecedent gradient and greater amount of back barrier accommodation that allowed for their survival from transgressive ravinement processes (Green et al., 2013b). 


\section{Conclusions}

Barriers of microtidal estuaries in southern Africa form narrow features that comprise stratigraphies that are almost entirely dominated by overwash processes. Breaching of these barriers is common and associated with high wave events linked to intense storms. Breaching occurs due to washover channelling, evidenced by multiple small channels preserved evident in GPR data. Unlike most other barrier-inlet systems, the inlets are rapidly filled by washover sheets which limit the inlet's potential to migrate laterally. The rapid infilling is a result of the limited accommodation in the inlet due to the steep gradient of the inlet floor.

These barriers experience quasi-stable oscillations in their landward and seaward shore position. Their landward shorelines have shifted up to $100 \mathrm{~m}$ landward in response to the largest storm recorded for the area. This shift in geomorphic footprint alludes to the rolling over of these systems, where they currently oscillate in a quasi-stable position until further large storm activity shifts them again.

As these barriers are dominated by overwash, which is responsible in part for both the constructive and destructive phases of the barrier, their potential for preservation in the stratigraphic record is low. Guided by lagoon hypsometry, persistent storm-driven rollover will likely outpace the enlargement of accommodation space due to long-term sea-level rise. Once accommodation disappears, the barriers are eroded by subsequent storm activity.

Acknowledgements

We acknowledge the inputs of the associate editor and Dr. Ilya Buynevich, whose constructive and useful feedback aided in improving the manuscript. Kreesan Palan, Shannon Dixon, Keegan Benallack, Lauren Pretorius and Errol Wiles assisted in the field. T.P acknowledges a 
scarce skills scholarship from the National Research Foundation. This paper is a contribution to IGCP Project 639, Sea Level Change from Minutes to Millennia.

\section{References}

Almeida LP, Ferreira Ó, Vousdoukas M, Dodet G. 2011. Historical variation and trends in storminess along the Portuguese south coast. Natural Hazards and Earth System Sciences 11: $2407-2417$.

Aubrey DG, Giese GS. 1993. Formation and Evolution of Multiple Tidal Inlets, Coastal and Estuarine Studies. American Geophysical Union, Washington, D.C. 44, pp. 95-112.

Baldock TE, Weir F, Hughes MG. 2008. Morphodynamic evolution of a coastal lagoon entrance during swash overwash. Geomorphology 95: 398-411.

Belknap DF, Kraft JC. 1985. Influence of antecedent geology on stratigraphic preservation potential and evolution of Delaware's barrier systems. Marine Geology 63: 235- 262.

Bennett MR, Cassidy NJ, Pile J. 2009. Internal structure of a barrier beach as revealed by ground-penetrating radar (GPR): Chesil beach, UK. Geomorphology 104: 218-229

Bond J, Green AN, Cooper JAG, Humphries MS. 2013. Seasonal and episodic variability I the morphodynamics of an ephemeral inlet, Zinkwazi Estuary, South Africa. Journal of Coastal Research SI 65: 446-451.

Buynevich IV. 2007. Barrier-fronted saltponds (Cape Cod, USA) and limans (NW Black Sea, Ukraine): comparative morphostratigraphy and response to sea-level rise. Quaternary International 168: 12-18. 
Buynevich IV, FitzGerald DM. 2003. High-resolution subsurface (GPR) imaging and sedimentology of coastal ponds, Maine, U.S.A.: Implications for Holocene back-barrier evolution. Journal of Sedimentary Research 73: 559-571.

Buynevich IV, FitzGerald DM., van Heteren, S. 2004. Sedimentary records of intense storms in Holocene barrier sequences, Maine, USA. Marine Geology 210:135-148.

Buynevich LV, Donnelly JP. 2006. Geological signatures of barrier breaching and overwash, southern Massachusetts, USA. Journal of Coastal Research SI39: 112-116.

Buynevich IV, FitzGerald DM, Goble RJ. 2007. A 1500 yr record of North Atlantic storm activity based on optically dated relict beach scarps. Geology 35: 543-546.

Carter RWG. 1986. The morphodynamics of beach-ridge formation: Magilligan, Northern Ireland. Marine Geology 73: 191-214.

Chew JA, Bowen, PR. 1971. The water resources of the coastal areas of northern Natal and Zululand. The Natal Town and Regional Planning Commission, Pietermaritzburg, South Africa, pp. 74.

Clarke DW, Boyle JF, Lario J, Plater AJ. 2014. Meso-scale barrier estuary disturbance, response and recovery behaviour: evidence of system equilibrium and resilience from highresolution particle size analysis. The Holocene 24: 357-369

Clarke DW, Boyle JF, Plater AJ. 2017. Particle-size evidence of barrier estuary regime as a new proxy for ENSO climate variability. Earth Surface Processes and Landforms 42: 15201534.

Clemmensen LB, Nielsen L. 2010. Internal architecture of a raised beach ridge system (Anholt, Denmark) resolved by ground-penetrating radar investigations. Sedimentary Geology 223: 281-290. 
Cooper JAG, Mason TR, Reddering JSV, Illenberger WK. 1990. Geomorphological effects of catastrophic flooding on a small subtropical estuary. Earth Surface Processes and Landforms 15: 25-41.

Cooper JAG. 1990. Ephemeral stream-mouth bars at flood-breach river mouths on a wavedominated coast: Comparison with ebb-tidal deltas at barrier inlets. Marine Geology 95: 57-

$$
70 .
$$

Cooper JAG. 1991, Shoreline changes on the Natal coast: Mkomanzi River mouth to Tugela River mouth. The Natal Town and Regional Planning Commission, Pietermaritzburg, South Africa Report 77: 12-48

Cooper JAG. 1993. Sedimentation in a river-dominated estuary. Sedimentology 40: 9791017.

Cooper JAG. 1994. Sedimentation in the river-dominated Mvoti estuary, South Africa. Geomorphology 9: 271-300.

Cooper JAG. 1995. Lagoons and microtidal coasts. In Coastal Evolution, Carter RWG, Woodroffe CD (eds). Cambridge University Press: Cambridge; 219-265.

Cooper JAG. 2001a. Geomorphological variability among microtidal estuaries from the wave-dominated South African coast. Geomorphology 40: 99-122.

Cooper JAG. 2001b. Geomorphology of Tide-dominated and River-dominated, Barred, Microtidal Estuaries: a Contrast. Journal of Coastal Research 34: 428-436.

Cooper JAG. 2002. The role of extreme floods in estuary-coastal behaviour: contrasts between river- and tide-dominated microtidal estuaries. Sedimentary Geology 150: 123-137. 
Cooper JAG, Green AN. 2016. Geomorphology and preservation potential of coastal and submerged aeolianite: examples from KwaZulu-Natal, South Africa. Geomorphology 271: 112.

Cooper JAG, Green AN, Loureiro C. 2018. Geological constraints on mesoscale coastal barrier behaviour. Global and Planetary Change 168: 15-34.

Costas S, Alejo I, Rial F, Lorenzo H, Nombela MA. 2006. Cyclical Evolution of a Modern Transgressive Sand Barrier in Northwestern Spain Elucidated by GPR and Aerial Photos. Journal of Sedimentary Research 76: 1077-1092.

Costas S, FitzGerald DM. 2011. Sedimentary architecture of a spit-end (Salisbury Beach, Massachusetts): The imprints of sea-level rise and inlet dynamics. Marine Geology 284: 203216.

Costas S, Ferreira Ó, Plomaritis TA, Leorri E. 2016. Coastal barrier stratigraphy for Holocene high-resolution sea-level reconstruction. Scientific Reports 6: 38726.

Daly J, McGeary S, Krantz DE. 2002. Ground-penetrating radar investigation of a late Holocene spit complex: Cape Henlopen, Delaware. Journal of Coastal Research 18: 274-286.

Davies JL. 1964. A morphogenic approach to world shorelines. Zeitschrift für Geomorphologie 8: 127-142.

Dougherty AJ. 2014. Extracting a record of Holocene storm erosion and deposition preserved in the morphostratigraphy of a prograded coastal barrier. Continental Shelf Research 86 :

$116-131$.

Dougherty AJ., FitzGerald DM Buynevich IV. 2004. Evidence for storm-dominated early progradation of Castle Neck barrier, Massachusetts, USA. Marine Geology 210:123-134. 
Elwany MHS, Flick RE, Aijaz S. 1998. Opening and closure of a marginal southern

California lagoon inlet. Estuaries 21: 246-254.

FitzGerald, D. M., Buynevich IV, Rosen PS. 2001. Geological evidence of former tidal inlets along a retrograding barrier: Duxbury, Massachusetts, USA. Journal of Coastal Research 34: $436-448$

FitzGerald DM, Georgiou I, Miner M. 2015. Estuaries and tidal inlets: Coastal Environments and Global Change: 268-298.

FitzGerald DM, Buynevich I, Hein C. 2012. "Morphodynamics and facies architecture of tidal inlets and tidal deltas." Principles of Tidal Sedimentology. Springer: Dordrecht: 301333.

Folk RL, Ward WC. 1957. Brazos River bar: a study in the significance of grain size parameters. Journal of Sedimentary Petrology 27: 3-26.

Froneman PW. 2004. Food web dynamics in a temperate temporarily open/closed estuary (South Africa). Estuarine, Coastal and Shelf Science 59: 87-95.

Garden SE, Garland GG. 2005. Spit development in the Mdloti River estuary, KwaZuluNatal. South African Journal of Geology 108: 257-270.

Guisado-Pintado E, Jackson DWT. 2018.Multi-scale variability of storm Ophelia 2017: The importance of synchronised environmental variables in coastal impact. Science of The Total Environment 630: 287-301.

Green AN, Cooper JAG, Le Vieux A. 2013a. Unusual barrier/inlet behaviour associated with active coastal progradation and river-dominated estuaries. Journal of Coastal Research SI69: $35-45$. 
Green AN, Cooper JAG, Salzmann L. 2014. Geomorphic and stratigraphic signals of postglacial meltwater pulses on continental shelves. Geology 42: 151-154.

Green AN, Cooper JAG, Salzmann L. 2018. The role of shelf morphology and antecedent setting in the preservation of palaeo-shoreline (beachrock and aeolianite) sequences: the SE African shelf. Geo-Marine Letters 38: 5-18.

Green AN, Dladla N, Garlick LG. 2013b. Spatial and temporal variations in incised valley systems from the Durban continental shelf, KwaZulu-Natal, South Africa. Marine Geology 335: $148-161$.

Haines PE, Tomlinson RB, Thom BG. 2006. Morphometric assessment of intermittently open/closed coastal lagoons in New South Wales, Australia. Estuarine, Coastal and Shelf Science 67: 321-332.

Hein CJ, FitzGerald DM, Carruthers EA, Stone BD, Barnhardt WA, Gontz AM. 2012. Refining the model of barrier island formation along a paraglacial coast in the Gulf of Maine. Marine Geology 307-310: 40-57.

Hein CJ, Fitzsimons GG, FitzGerald DM, Fallon AR. 2016. Records of migration and ebbdelta breaching at historic and ancient tidal inlets along a river-fed paraglacial barrier island. Journal of Coastal Research, SI75: 228-232.

Heydorn AEF, Pistorius RA. 1978. The Estuaries of Natal. Backhouse: Pietermaritzburg; 657.

Hine AC. 1979. Mechanisms of berm development and resulting beach growth along a barrier spit complex. Sedimentology 26: 333-351.

Kraft JC, John JC. 1979. Lateral and vertical facies relations of transgressive barrier. The American Association of Petroleum Geologists Bulletin 63: 2145-2163. 
Loureiro C, Ferreira Ó, Cooper JAG. 2012. Geologically constrained morphological variability and boundary effects on embayed beaches. Marine Geology 329:1-15.

Maio CV, Gontz AM, Sullivan RM, Madsen SM, Weidman CR, Donnelly JP. 2014.

Subsurface Evidence of Storm-Driven Breaching along a Transgressing Barrier System, Cape Cod, U.S.A. Journal of Coastal Research 32: 264-279

Masselink G, Scott T, Conley D, Davidson M, Russell P. 2015. Regional variability in Atlantic storm response along the southwest coast of England. Proceedings Coastal

Sediments, ASCE, San Diego, USA.

McCormick S, Cooper JAG, Mason TR. 1992. Fluvial sediment yield to the Natal coast: a review. South African Journal of Aquatic Sciences 18: 74-88.

Moes H, Rossouw M. 2008. Considerations for the utilization of wave power around South Africa. Workshop on Ocean Energy: Centre for Renewable and Sustainable Energy Studies: Stellenbosch (21 February 2008, Abstracts).

Morris BD, Turner IL. 2010. Morphodynamics of intermittently open-closed coastal lagoon entrances: New insights and a conceptual model. Marine Geology 271: 55-66.

Moslow TF, Heron SD. 1978. Relict inlets; preservation and occurrence in the Holocene stratigraphy of southern core banks, North Carolina. Journal of Sedimentary Research 48, $1275-1286$.

Oertel GF. 1985. The barrier island system. Marine Geology 63: 1-18

Pascucci V, Martin IP, Endres AL. 2009. Facies and ground-penetrating radar characteristics of coarse-grained beach deposits of the uppermost Pleistocene glacial Lake Algonquin, Ontario, Cảnada. Sedimentology 56: 529-545. 
Reinson GE. 1992. Transgressive barrier island and estuarine systems. In Facies Models:

Response to Sea Level Change, Walker RG (ed). Geological Association of Canada: 179-194

Rooseboom A. 1975. Sediment produksiekaart vir Suid- Afrika. Department of Water Affairs and Environmental Conservation Technical report: 61.

Roy PS. 1984. New South Wales estuaries: their origin and evolution. In Coastal

Geomorphology in Australia, Thom BG (ed). Academic Press: Australia; 99-121.

Roy PS, Williams RJ, Jones AR, Yassini I, Gibbs PJ, Coates B, West RJ, Scanes PR, Hudson

JP, Nichol S. 2001. Structure and function of south-east Australian estuaries. Estuarine,

Coastal and Shelf Science 53: 351-384.

Salzmann L, Green AN. 2012. Boulder emplacement on a tectonically stable, wave-

dominated coastline, Mission Rocks, northern KwaZulu-Natal, South Africa. Marine

Geology 323: 95-106.

Seminack CT, Buynevich IV. 2013. Sedimentological and geophysical signatures of a relict tidal inlet complex along a wave-dominated barrier: Assateague Island, Maryland, U.S.A. Journal of Sedimentary Research 83: 132-144.

Shan X, Yu X, Clift PD, Tan C, Jin L, Li M, Li W. 2015. The groun-penetrating radar facies and architecture of a paleo-spit from Huangqihai Lake, North China: Implications for genesis and evolution. Sedimentary Geology 323: 1-14.

Smith AM, Mather AA, Bundy SC, Cooper JAG, Guastella LA, Ramsay PJ, Theron A. 2010. Contrasting styles of swell-driven coastal erosion: examples from KwaZulu-Natal, South Africa. Geological Magazine 147: 940-953.

Smith AM, Bundy SC, Cooper JAG. 2016. Apparent dynamic stability of the southeast African coast despite sea level rise. Earth Surface Processes and Landforms 41: 1494-1503. 
Storms JEA, Weltje GJ, Terra GJ, Cattaneo A, Trincardi F. 2008. Coastal dynamics under conditions of rapid sea-level rise: late Pleistocene to early Holocene evolution of barrierlagoon systems on the northern Adriatic shelf (Italy). Quaternary Science Reviews 27: 11071123

Tanner WF. 1969. The particle size scale. Journal of Sedimentary Research, 39: 809-812.

Tillmann T, Wunderlich J. 2013. Barrier rollover and spit accretion due to the combined action of storm surge induced washover events and progradation: Insights from groundpenetrating radar surveys and sedimentological data. Journal of Coastal Research 65: 600605.

Tye RS, Moslow TF. 1993. Tidal inlet reservoirs: insights from modern examples. In Marine Clastic Reservoirs: Examples and Analogues: Frontiers in Sedimentary Geology, Rodhes EG, Moslow TF, (eds). Springer-Verlag: Berlin; 77-99.

Van Heteren S, FitzGerald DM, Mckinlay PA, Buynevich IV. 1998. Radar facies of paraglacial barrier systems: coastal New England, USA. Sedimentology 45: 181-200. 


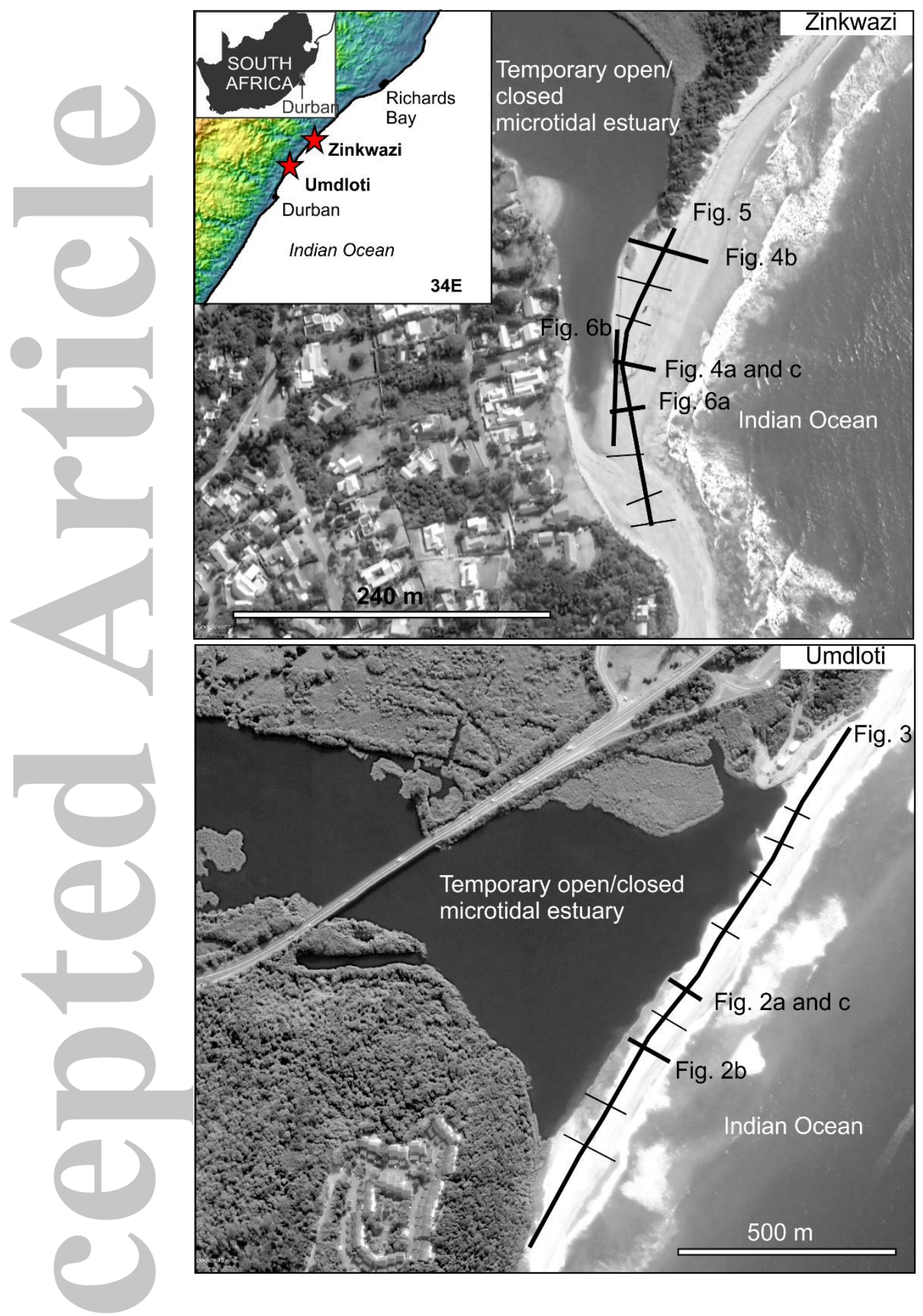

Figure 1. Locality map of the two study sites, together with the location of the various GPR profiles.

This article is protected by copyright. All rights reserved. 


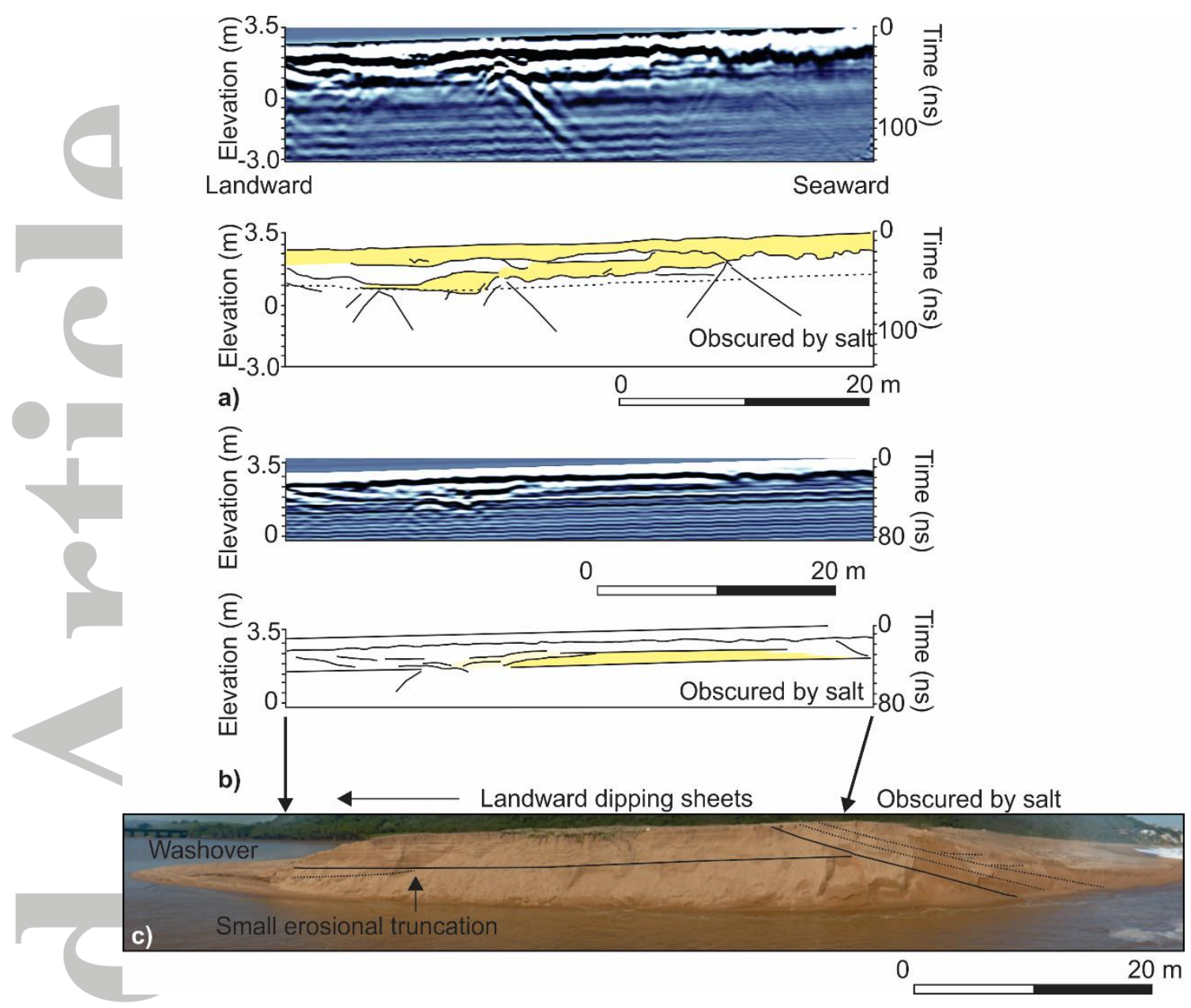

Figure 2. Coast-perpendicular GPR profiles through the Umdloti barrier. Note the dominance of landward dipping reflectors, with occasional lobes, the bases of which are marked by multiple hyperbolics. Lowermost image is of a freshly cut scarp in the barrier. Note the strongly landward dipping planar sheets to landward of the barrier crest. These are truncated by the seaward dipping beachface sediments, not clearly imaged in the GPR due to salt attenuation. 

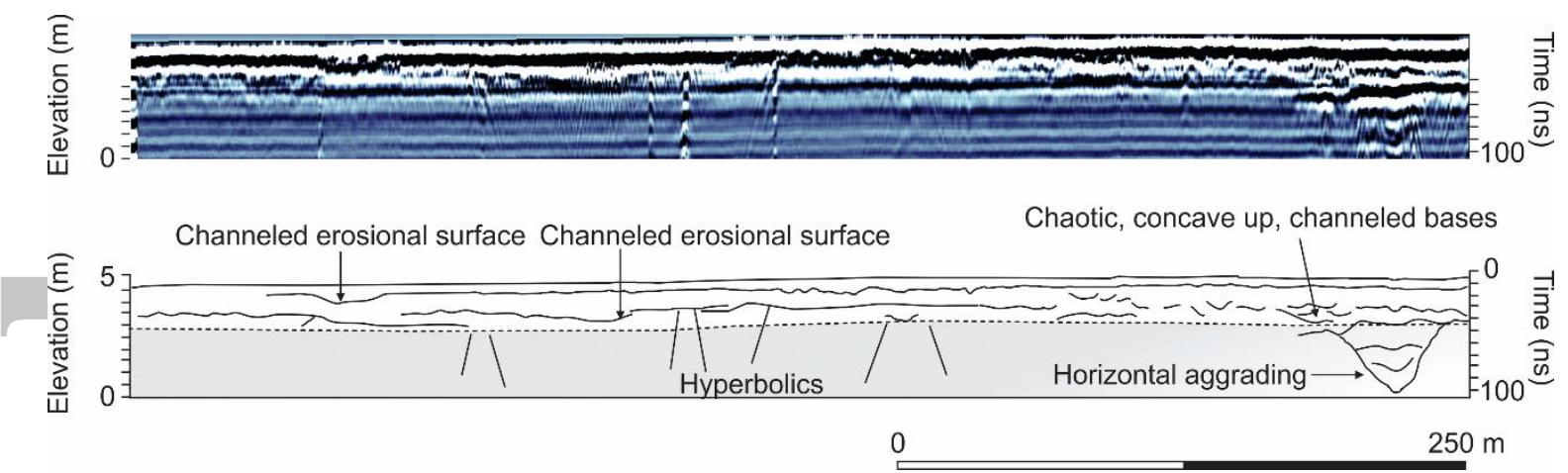

Figure 3. Coast-parallel GPR profile and interpretation from Umdloti barrier. Note the single channel-form preserved in the north, and multiple hyperbolics associated with smaller channelled features which truncate the larger channel. 

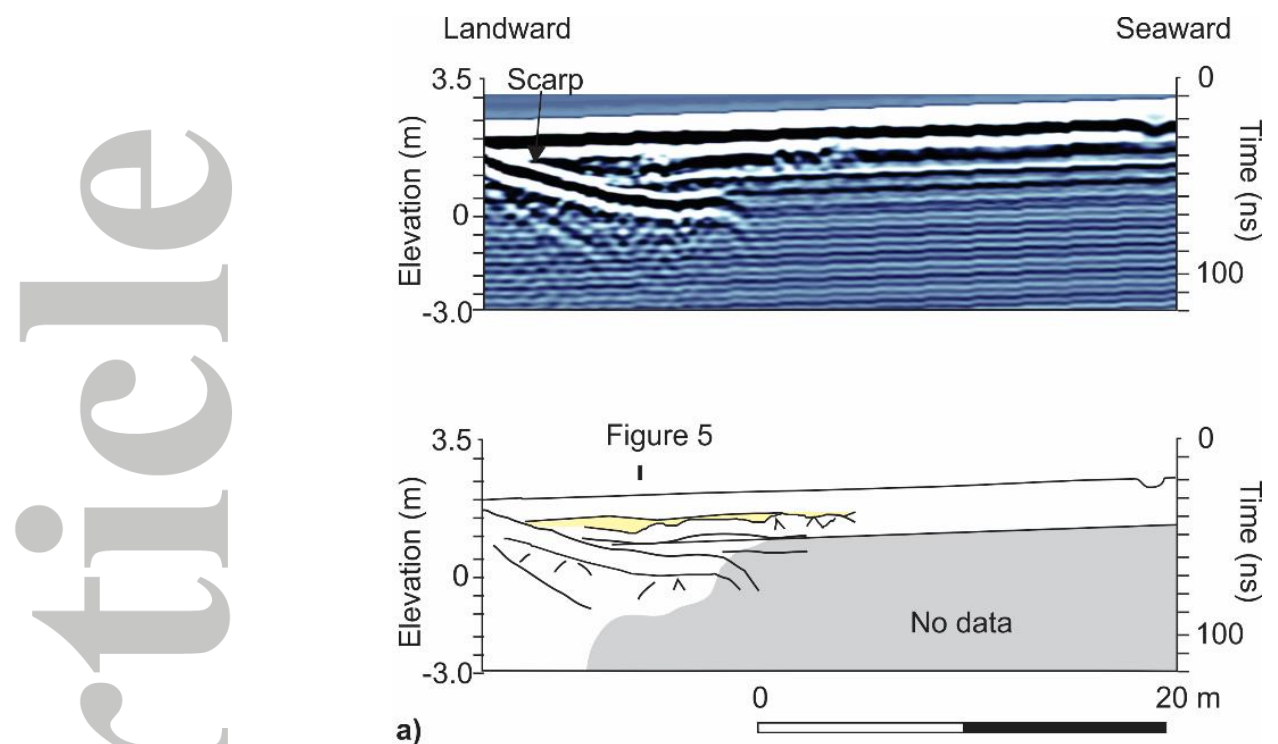

a)
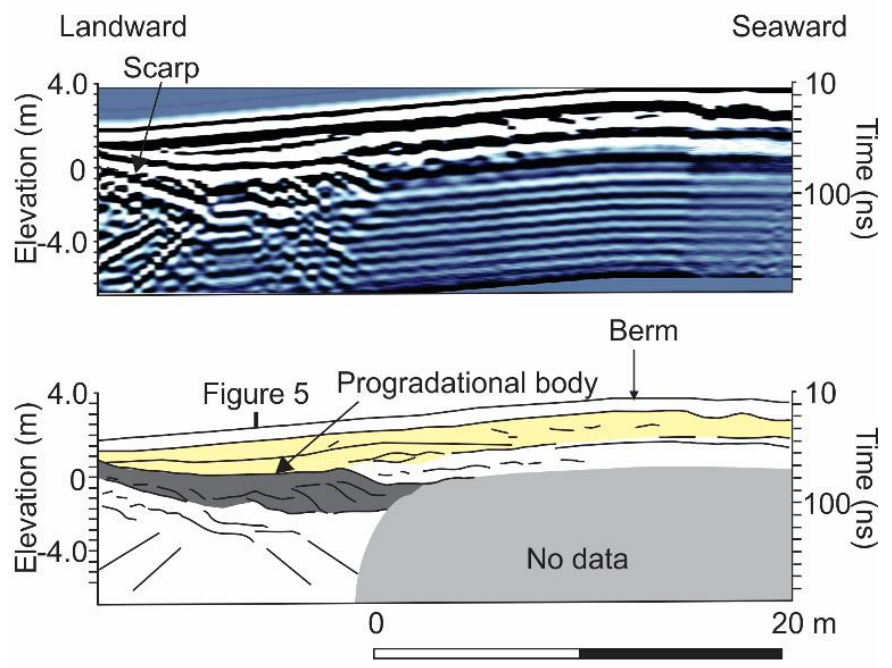

b)

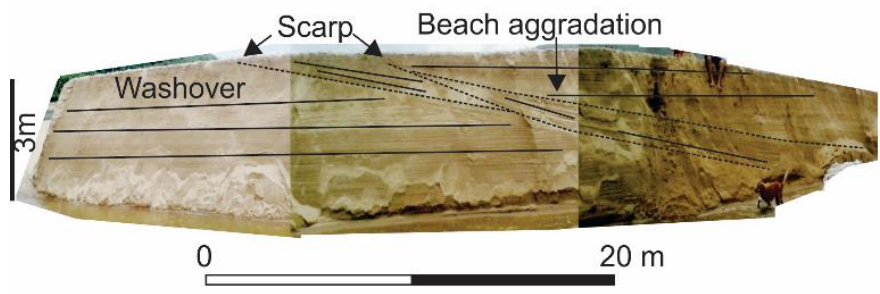

c)

Figure 4. Coast-perpendicular GPR profiles from the Zinkwazi barrier. Note the general landward dipping trend of the reflectors. A small progradational body onlaps a seawardoriented palaeo-scarp that in turn truncates more landward dipping reflectors. The lower image is of a cross section through the barrier. Note the gently landward dipping strata, truncated by several scarps over which an aggrading package of material overlies that marks the contemporary beachface. 
$\mathrm{S}$

$\mathrm{N}$
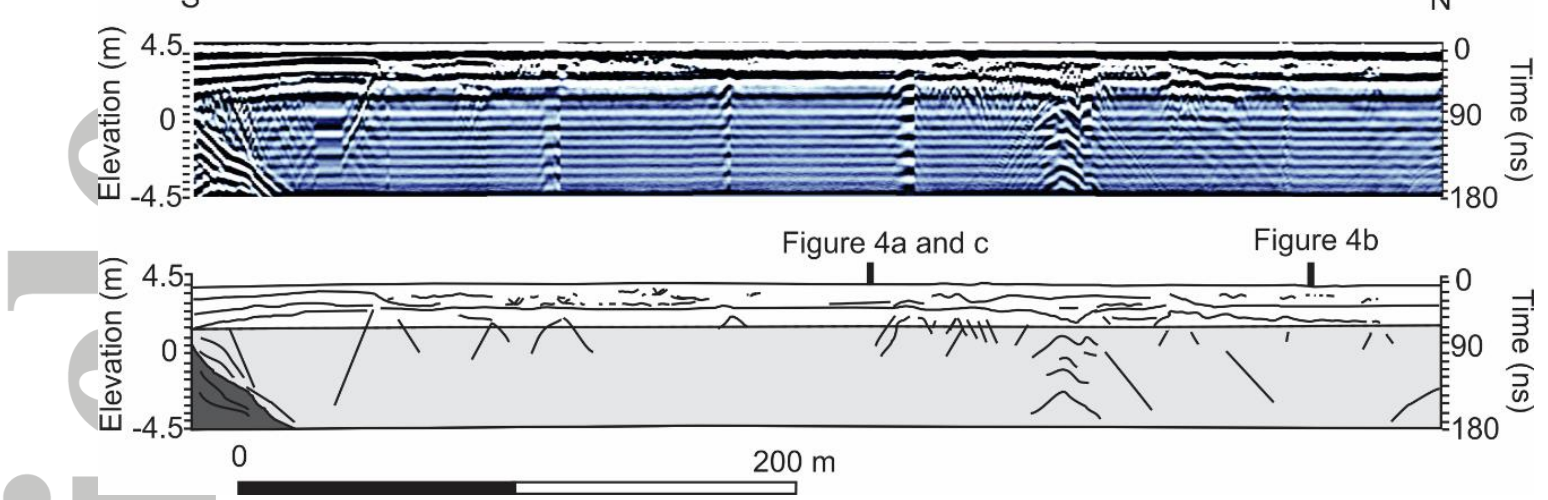

Figure 5. Coast-parallel GPR profile of the Zinkwazi barrier. Note the small channels and associated hyperbolics throughout the profile. In the south, the steeply inclined reflectors can be raced into adjoining bedrock. 


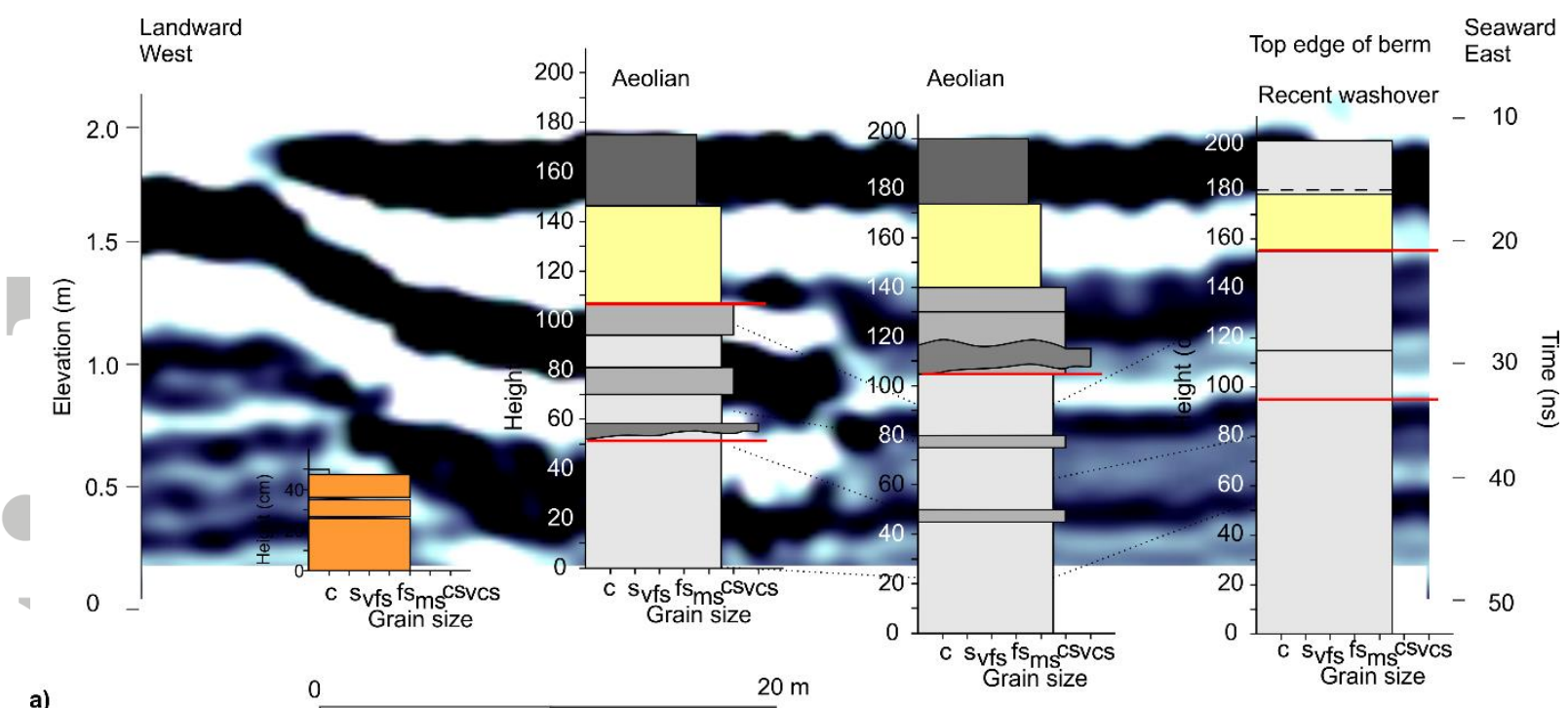

a) 0

Line 52 North

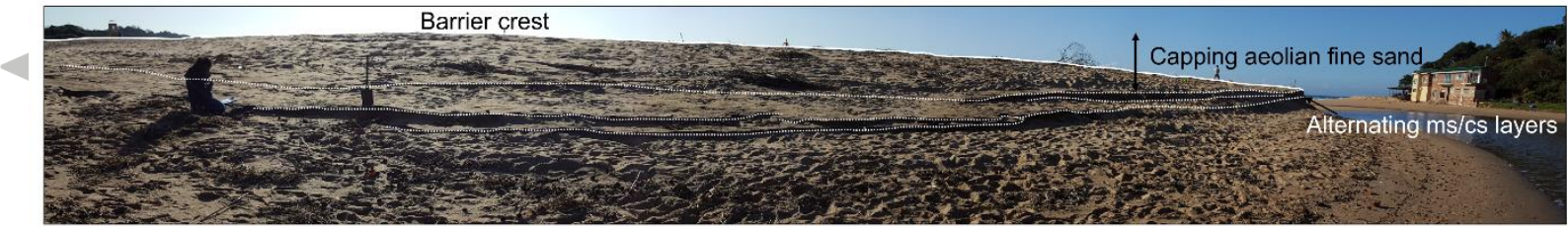
b)

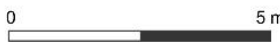

Figure 6. Detailed sedimentary architecture of the Zinkwazi barrier. Top image is a series of sections overlain relative to their position on the high-frequency GPR line. Note the links between grain size peaks and strongly reflective layers. These mark washover events, evident form the increasing grain size and increasing shell and heavy mineral content. Lower image shows a view of the barrier to seawards. The barrier crest is capped by fine aeolian sands, and were small scarps are evident to the southern section, these mark alternations between the

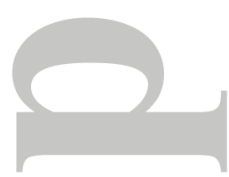
coarser washover layers and aeolian inputs. 

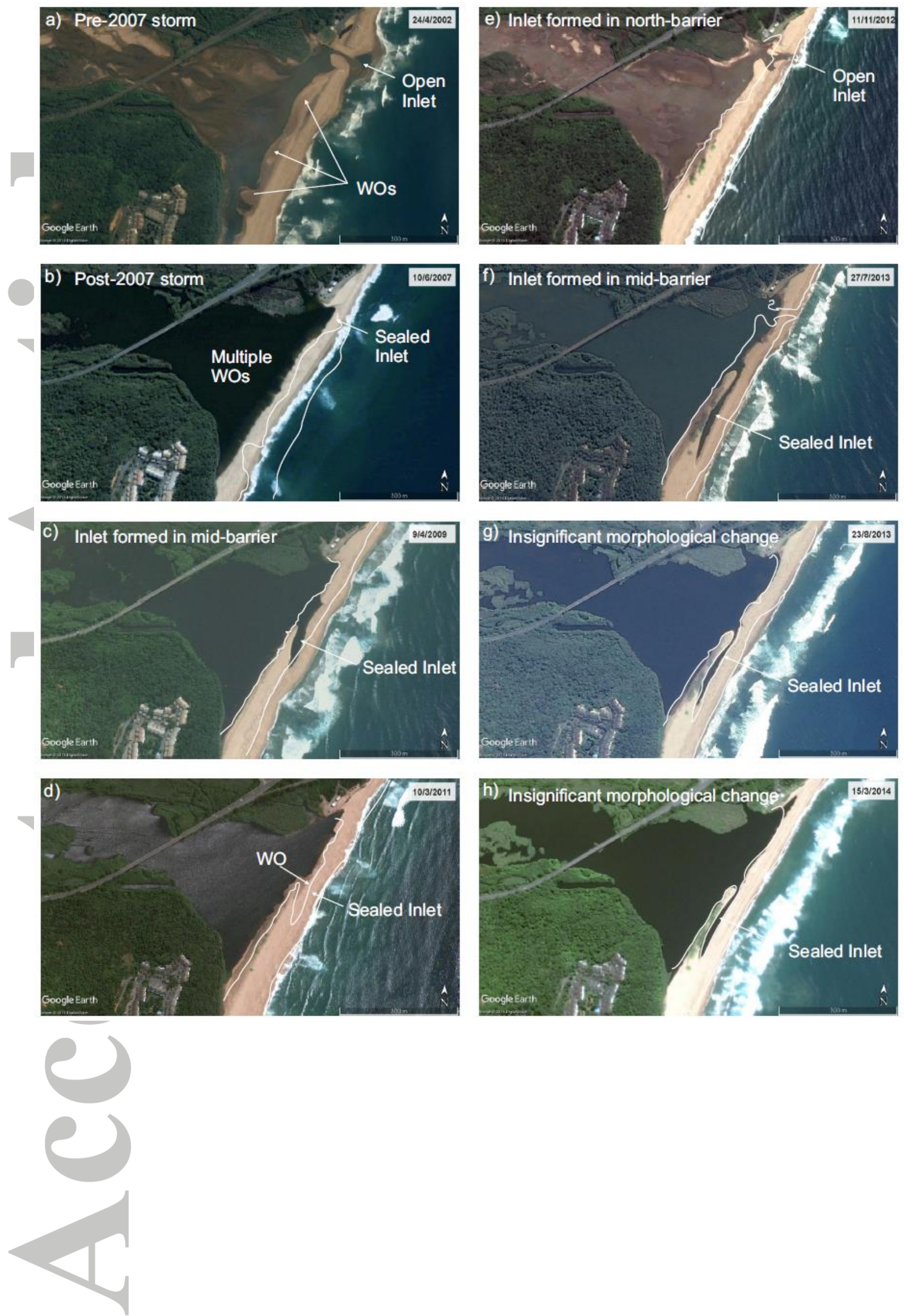

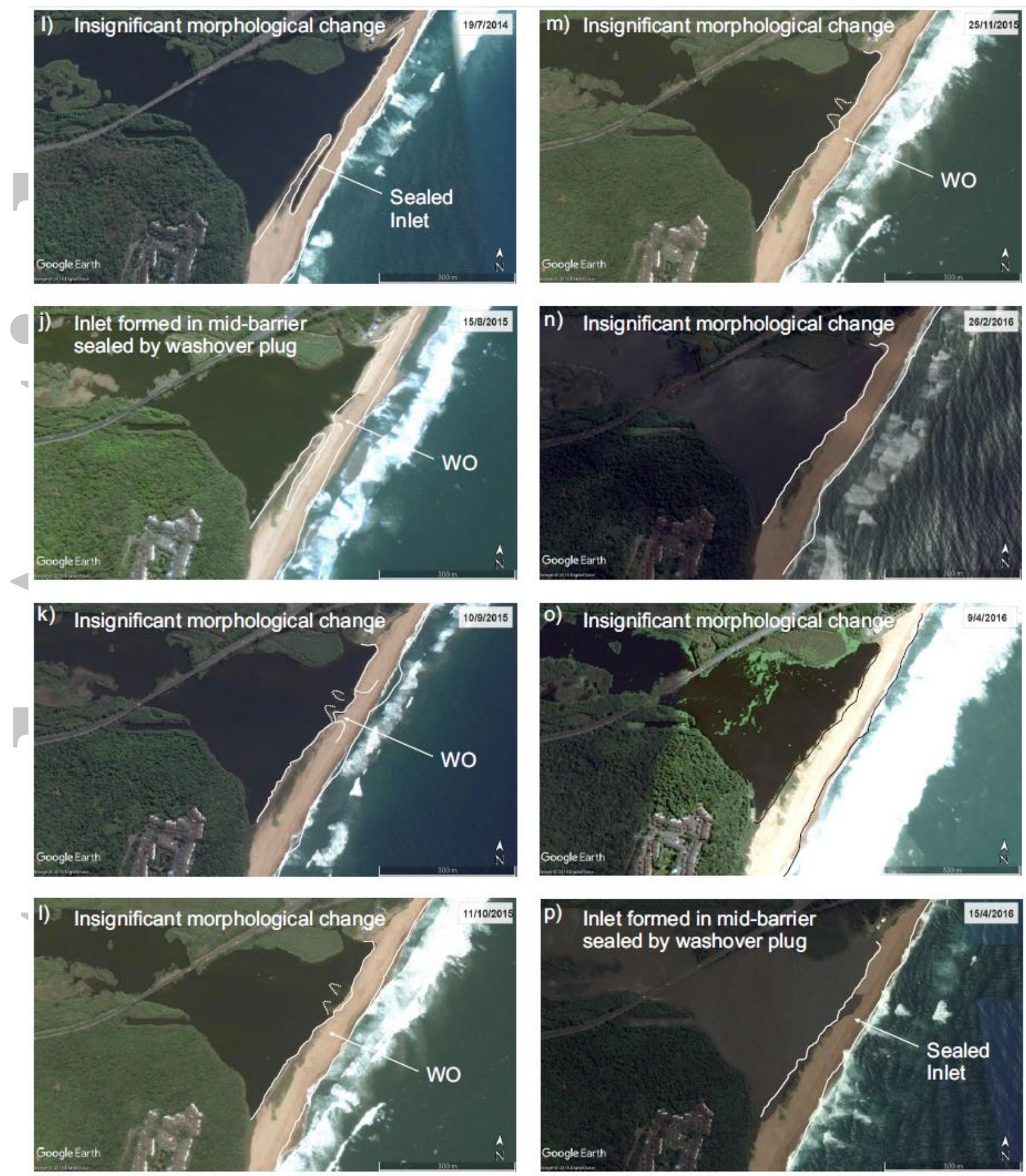

Figure 7. Time series satellite imagery of the Umdloti system. White lines the preceding shoreline position from the previous image. $\mathrm{WO}=$ washover. 

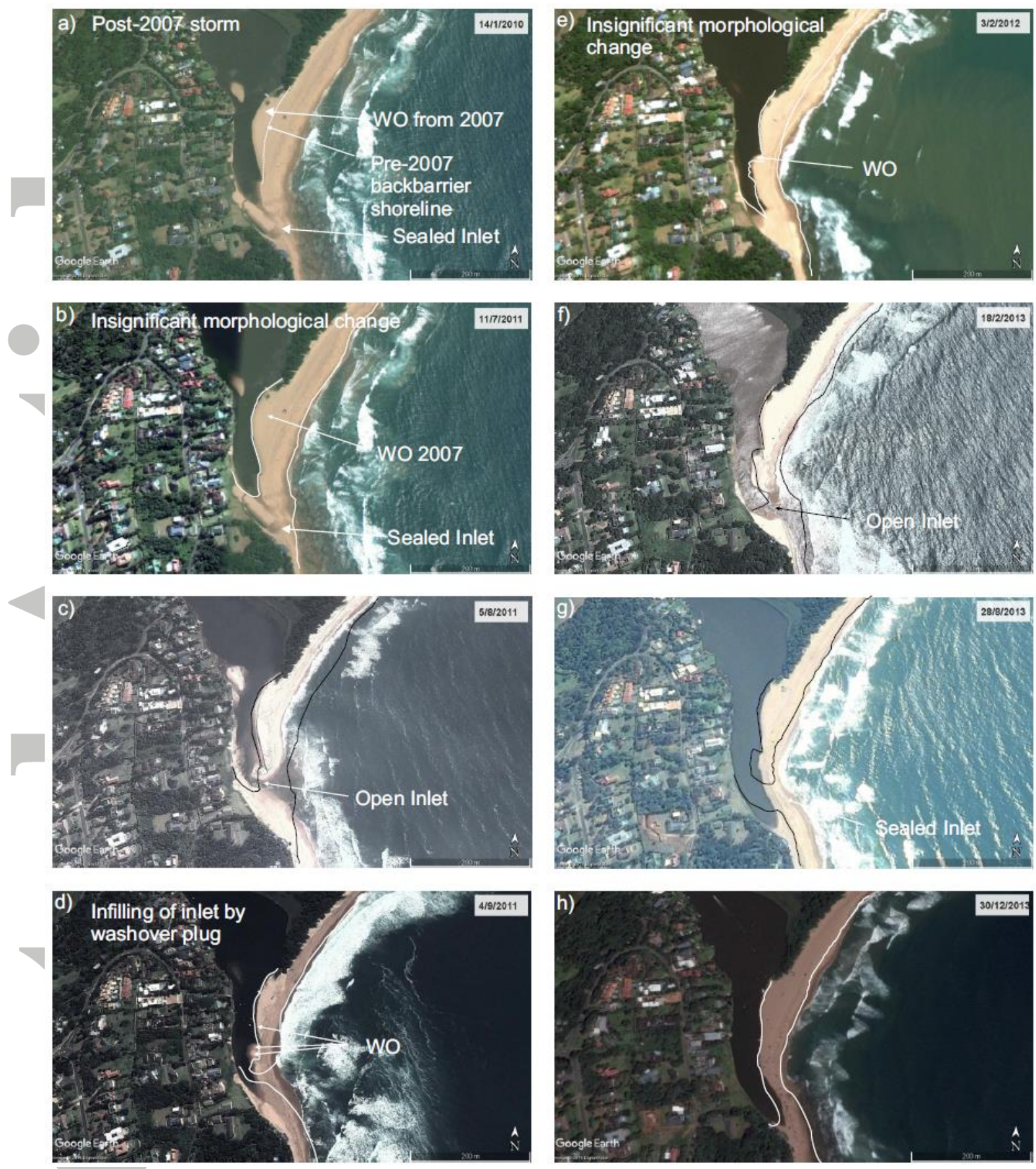

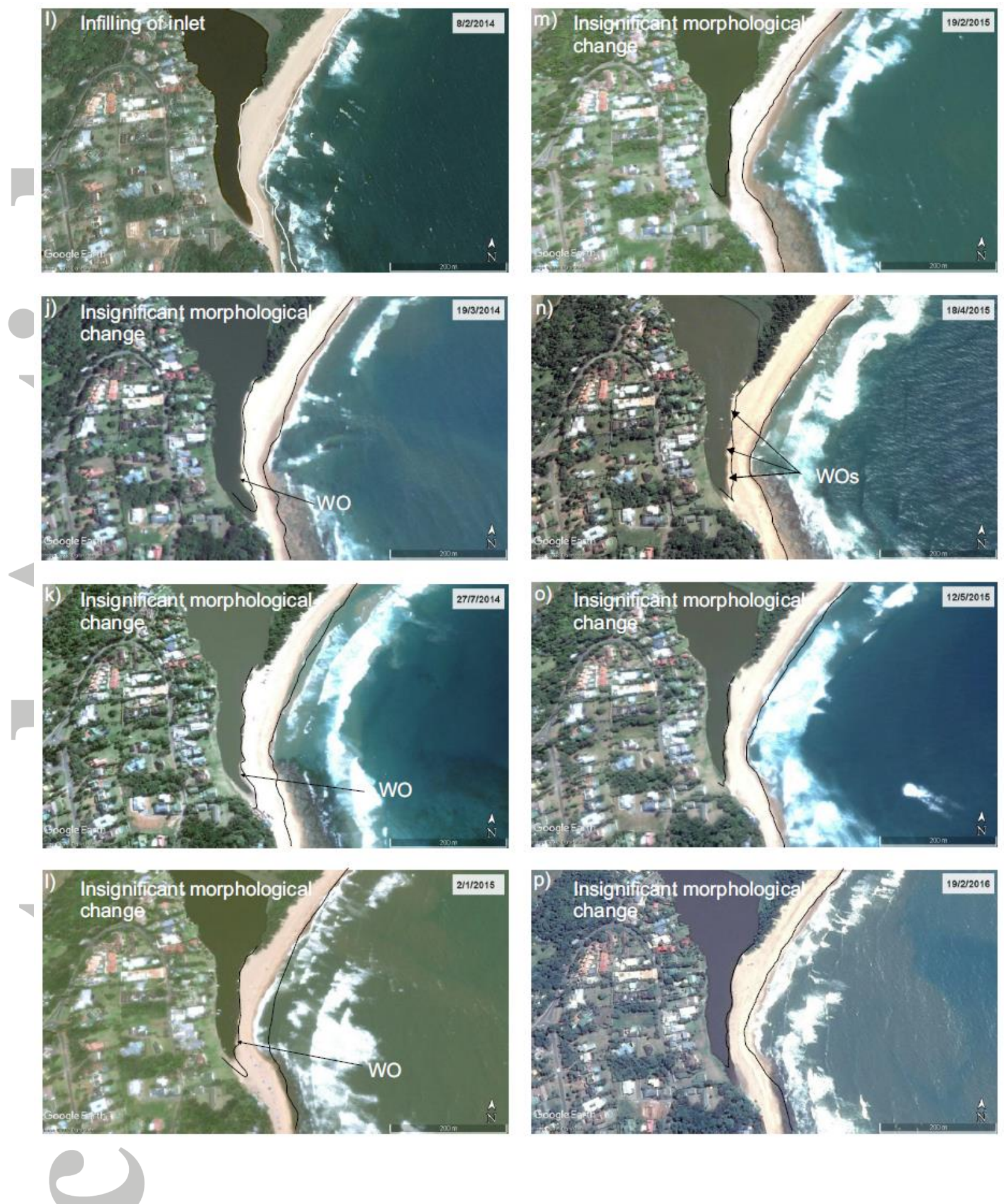

Figure 8. Time series satellite imagery of the Zinkwazi system. White lines the preceding shoreline position from the previous image. $\mathrm{WO}=$ washover.

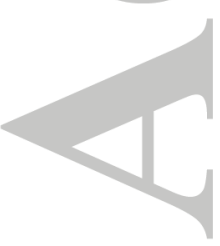




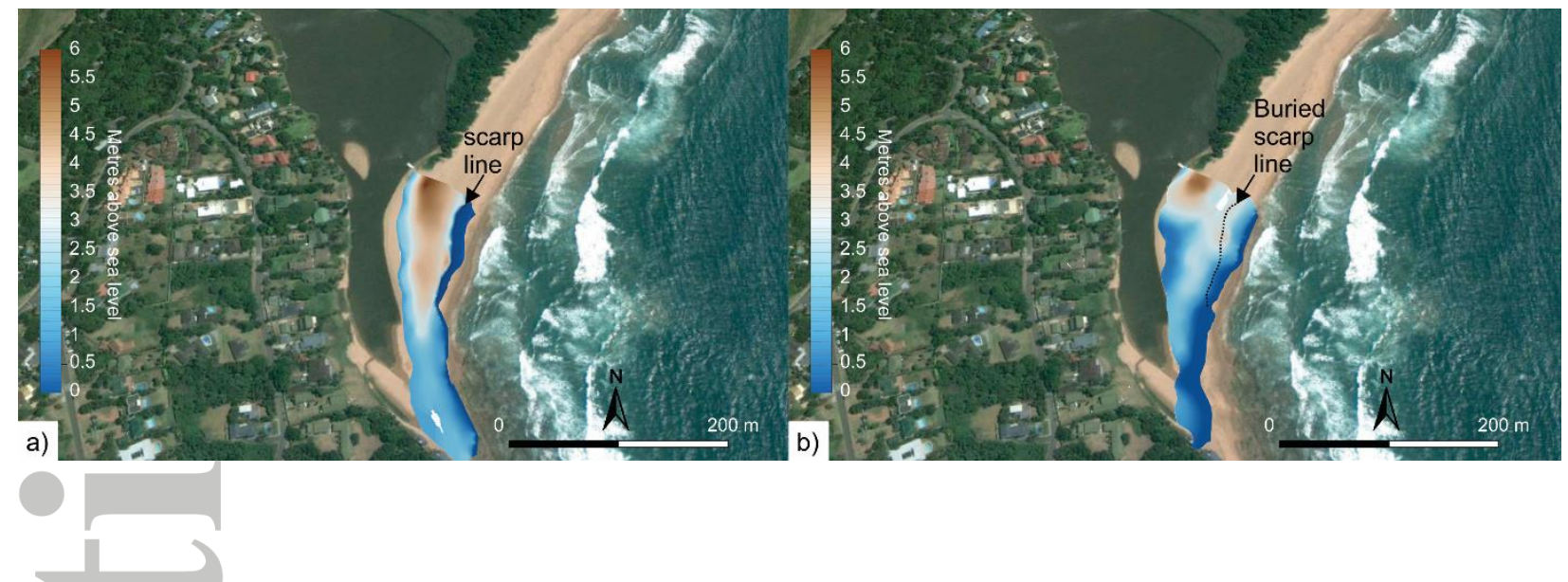

Figure 9. Pre-March 2007 (left) and post-March 2007 (right) digital terrain models modified from Bond et al. (2014). Note the pre-existence of a well-defined scarp that is buried by sediment influx of the March 2007 event. This scarp is evident in the GPR profiles shown in figure 4. In turn, scarping and retreat of the seaward front of the system around the rocky

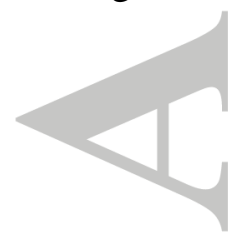
headland, by up to $60 \mathrm{~m}$, is also evident.

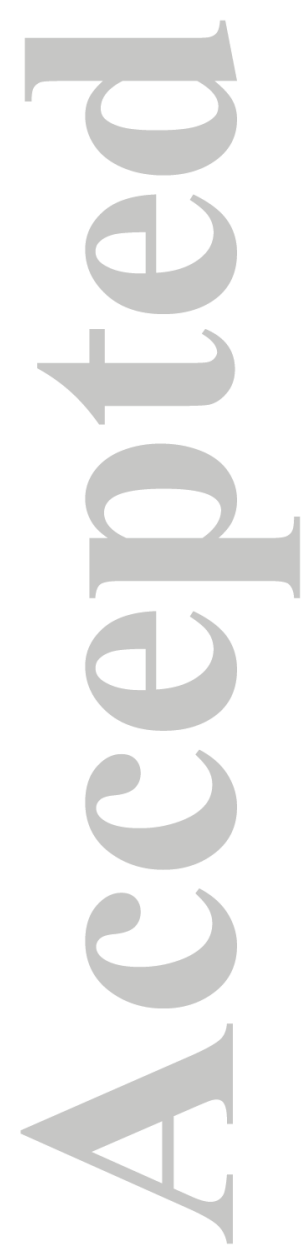




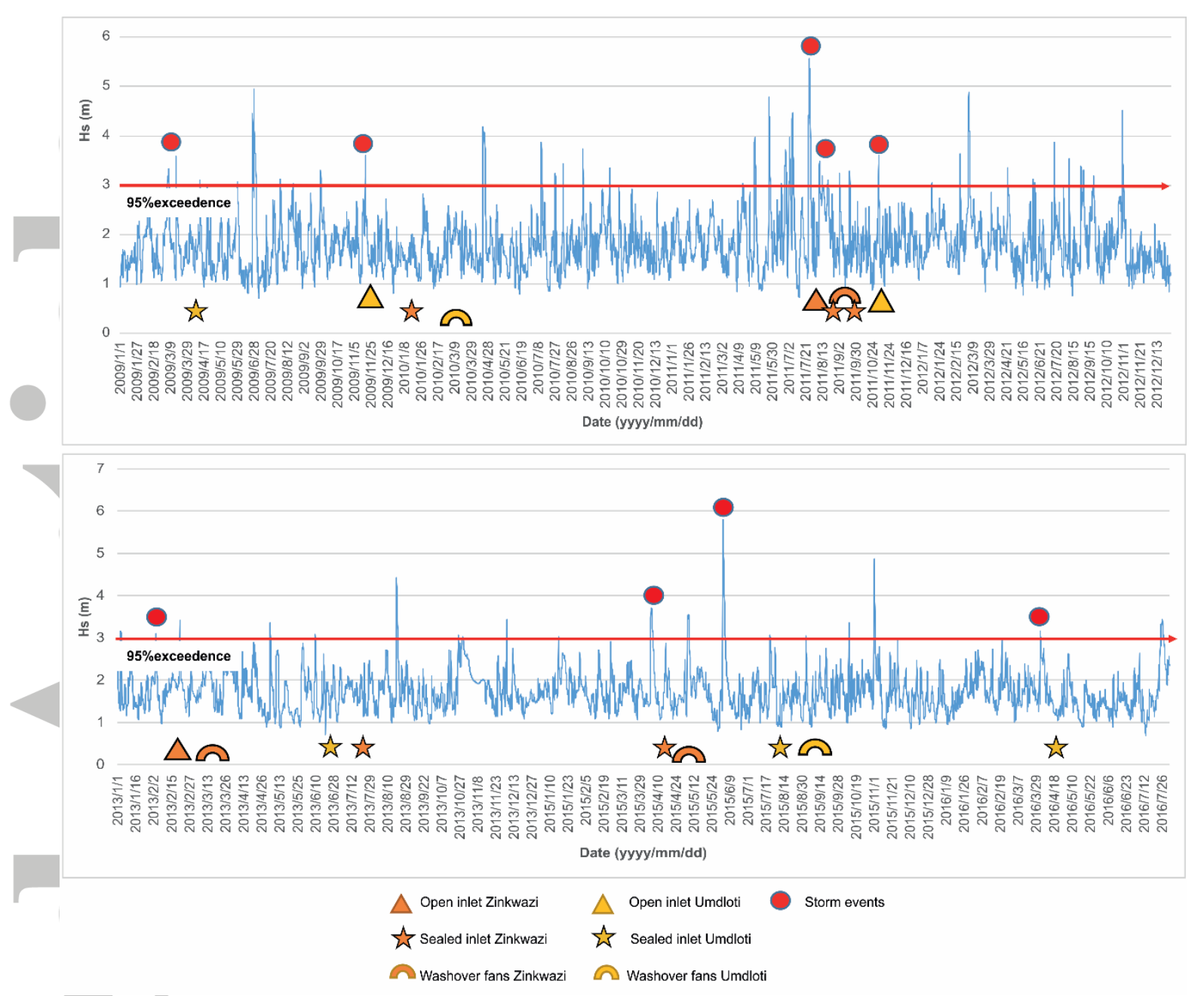

Figure 10. Time series analysis of wave records from the WW3 NCEP model for the period 2009-2016. Note the relationship between the opening and sealing of the inlets at both sites and their relationship with high-energy storms events. 
Table 1. Extreme swell events $>5 \mathrm{~m}$ significant swell heights $\left(\mathrm{H}_{\mathrm{so}}\right)$ recorded at the Richards Bay buoy. $\mathrm{H}_{\text {so }}$ is arranged in order of descending magnitude.

\begin{tabular}{|llccccc}
\hline Year & Month & Day & Significant & Extreme & $\begin{array}{c}\text { Wave } \\
\text { Period (s) }\end{array}$ & $\begin{array}{c}\text { Wavelength } \\
(\mathbf{m})\end{array}$ \\
\hline & & & $\mathbf{H}_{\mathbf{s o}}$ & $\mathbf{H}_{\mathbf{1}}$ & $\mathbf{T}_{\mathbf{p}}$ & $\mathbf{L}_{\mathbf{s o}}$ \\
\hline 2007 & March & 19 & 8.50 & 12.38 & 16.60 & 230.85 \\
\hline 1990 & October & 19 & 6.14 & 10.37 & 13.47 & 181.80 \\
\hline 1987 & September & 28 & 6.08 & 11.35 & 11.91 & 156.76 \\
\hline 1991 & August & 3 & 5.23 & 8.66 & 13.47 & 181.80 \\
\hline 2002 & September & 12 & 5.22 & 8.85 & 13.47 & 181.80 \\
\hline 2002 & July & 19 & 5.15 & 8.81 & 9.66 & 119.53 \\
\hline 1994 & July & 26 & 5.03 & 7.70 & 13.47 & 181.80 \\
\hline
\end{tabular}




\section{Graphical Abstract}

The barrier-inlet systems of the microtidal east coast of South Africa are driven by overwash processes. Inlets form by washover channelling and seal by washover plugging. The lowlying barriers and waterbody orientation typical of these systems predisposes them to backbarrier aggradation by overwash. Together with bedrock limitations on accommodation, these systems are especially vulnerable to rising sea level. Their geomorphic end point involves continual roll over, back-barrier infilling and ultimate destruction by wave erosion.
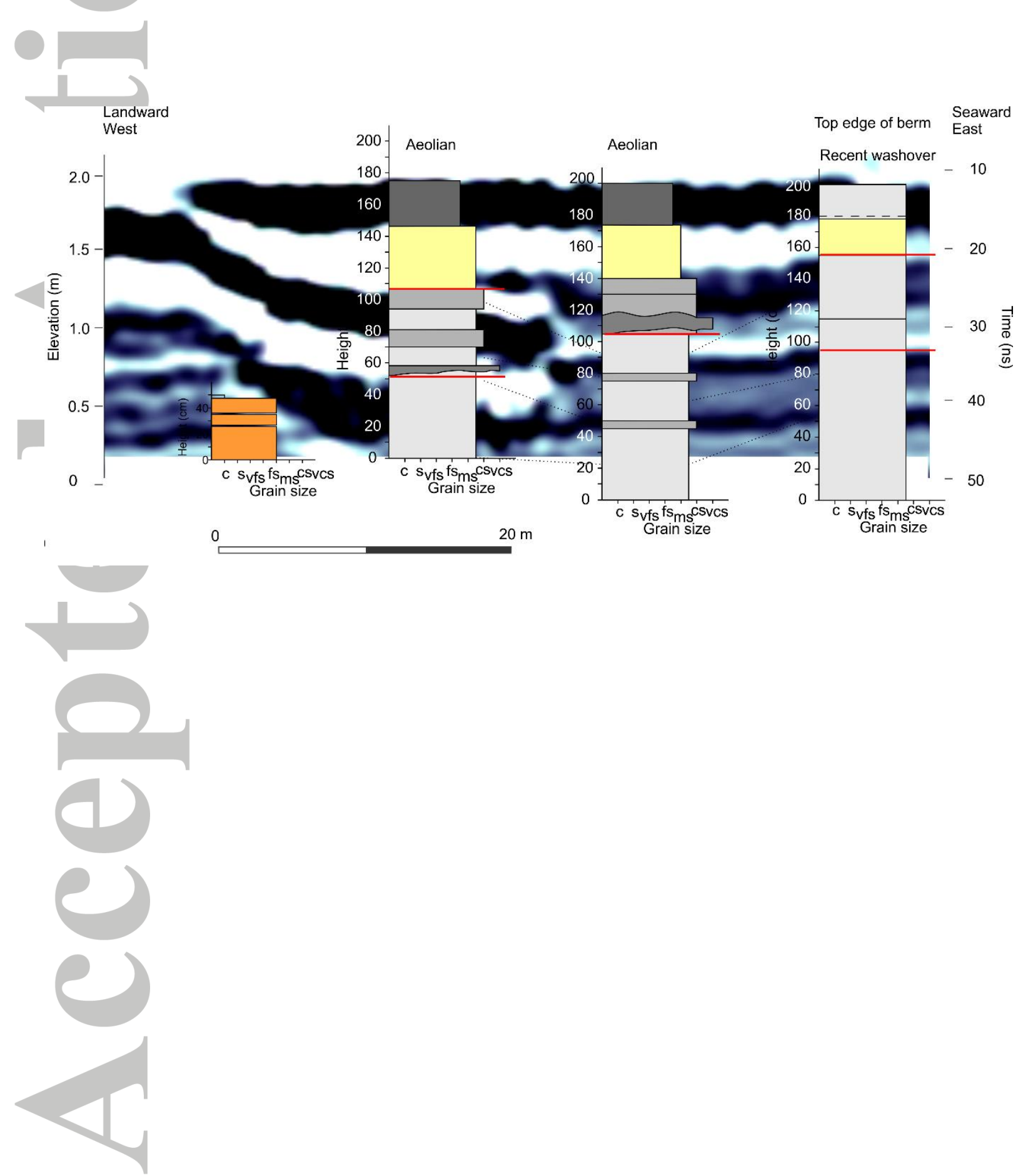